Institutional Report

\title{
Research Status at Wadia Institute of Himalayan Geology (WIHG), Dehradun During 2015-2019
}

KALACHAND SAIN*, RAJESH SHARMA, SUSHIL KUMAR, D P DOBHAL, VIKRAM GUPTA, PRADEEP SRIVASTAVA, R JAYANGONDAPERUMAL and KAPESA LOKHO

Wadia Institute of Himalayan Geology, 33, General Mahadeo Singh Road, Dehradun 248 001, India

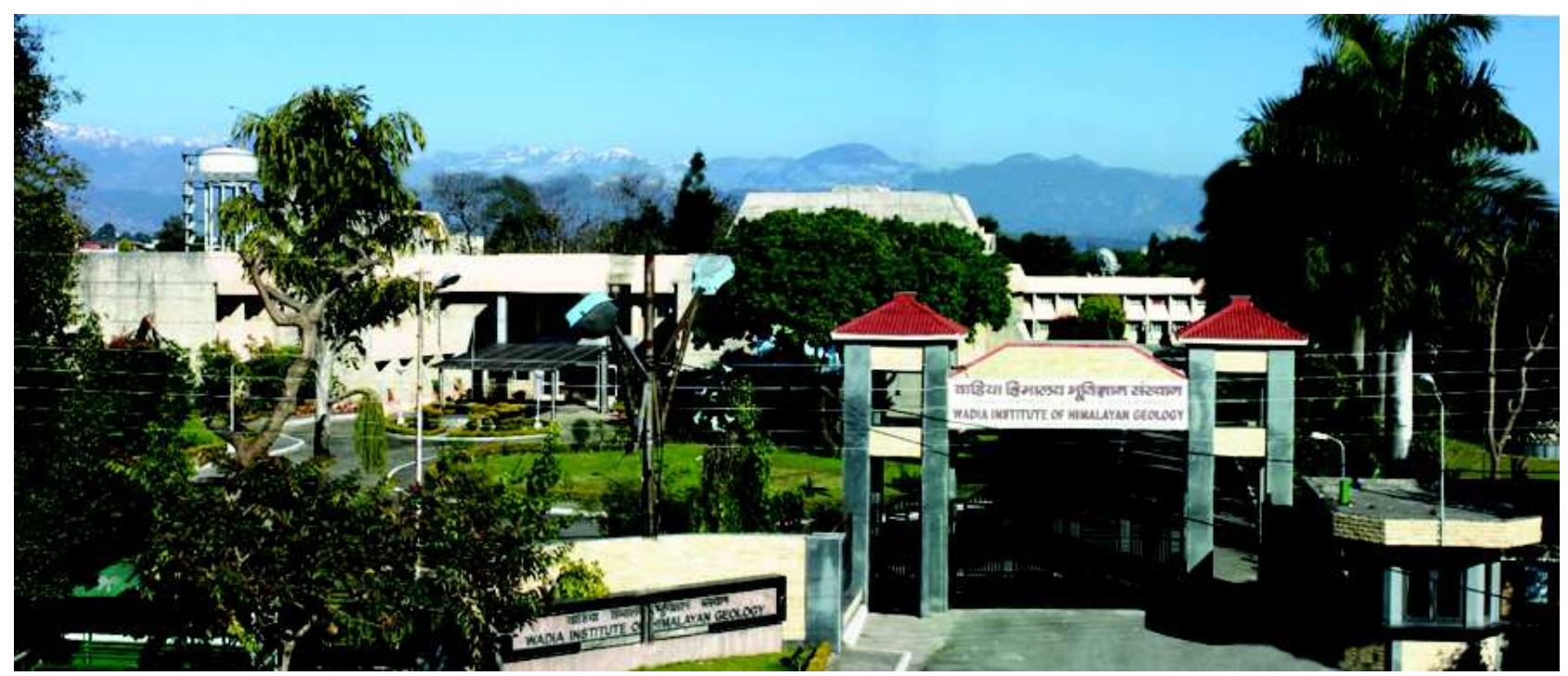

Fig. 1: The campus of Wadia Institute of Himalayan Geology at Dehradun

\section{The Institute}

The Wadia Institute of Himalayan Geology (WIHG) at Dehradun is an autonomous institution of the Department of Science \& Technology (DST), GoI, which came into being in 1968. It has been pursuing basic researches to unravel the orogenic processes of majestic Himalaya and to provide improved understanding on seismogenesis, geodynamic processes, climate-tectonic interactions, evolution and extinction of life, ore formation, glaciology, river system, natural hazards (landslides, floods, and earthquakes), anthropogenic impact etc. towards the well-being of population and safeguarding the properties and structures in the Himalaya and adjoining regions. The research activities to understand the mountain building processes and shed light on above topics are based on observations made by using rudiments of structural geology, petrology, paleontology, stratigraphy, sedimentology, geomorphology, different branches of geophysics, remote sensing etc.

In the backdrop of wide-ranging claims on the likely impact of climate change on Himalayan glaciers and their far-reaching consequences on the Indian economy, the DST has established the 'Centre for Glaciology' at WIHG. The Institute has been nurturing a earthquake monitoring and precursory study system in an integrated manner by hosting 'Multi-Parametric Geophysical Observatory (MPGO)' at Ghuttu (Tehri), Uttarakhand. This is a unique set up to perceive changes in subsurface properties that may lead to earthquake precursory

*Author for Correspondence: E-mail: kalachandsain7@gmail.com 
study in the Himalayan region. The WIHG has established as many as 54 Broad Band Seismographs and 16 Acceleragraphs spread over H.P., Uttarakhand, J\&K, Punjab, Haryana and Arunachal Pradesh. Similarly, around 17 GPS instruments are installed in H.P., Uttarakhand, J\&K and Ladakh. The Institute is well equipped with sophisticated analytical instruments facilities run by competent scientists and technicians. The labs are being utilized by the research scientists of Wadia as well as researchers from state and central universities and other organizations. Some important instruments available in the Institute are LA-MC-ICPMS, Stable Isotope Mass Spectrometer, EPMA, ICPMS, XRF, SEM, XRD, Raman Spectrometer, TL/OSL, Magnetic Susceptibility meter etc. The institute also provides consultancy services for engineering projects, drinking and groundwater surveys, natural hazards, road and rail alignments in the Himalaya and adjoining region. The campus of WIHG is shown in Fig. 1. The vision of the Institute is "Questing for Himalayan Seismogenesis, Geodynamics, Natural Hazards, Climate Variability and Natural Resources through Geoscientific study to fulfill the Societal Needs and pursue Basic Sciences." The research activities of WIHG are mainly focused on the following themes:

\section{Theme 1: Geodynamic Evolution of the Himalaya and adjoining mountains}

The activities under this program deal with the deformation of crust in the context of fold and thrust belts, melt generation, metamorphism at various levels, and deep structures. It involves studies on the rate of Himalaya's uplift and related crustal shortening that is characterized by several stages of deformation on grain to outcrop scale. The deformation stages are also expressed in the form of degree and spatial pattern of metamorphism that rock sequences of the Himalaya exhibit, and thus act as a proxy record of the time and rock exhumation due to the evolution of the Himalaya. Understanding of inverted metamorphic sequences and their bearing on tectonics help in explaining the orogenic processes of the Himalaya.

\section{Theme 2: Indian Monsoon-Tectonic Interaction and Exhumation of the Himalaya}

For the Himalaya-Tibet orogenic system, there has been a long-standing debate on the inter-relation between monsoon precipitation patterns and the exhumation rate across the Himalaya. Recent studies show that tectonic deformation, climate and life interact in ways that are sometimes profound but not so obvious. The erosion of mass from the Earth's surface may determine if the tectonic deformation has taken place at a rapid space. Consequently, heavy precipitation, fast erosion and active faulting are predicted to be spatially correlated in an active orogenic belt like the Himalaya. There lies a challenge whether the continental scale changes result from the movement of Inter-Tropical Convergence Zone (ITCZ) or the focused erosion and its impact on crustal exhumation or from the deep-seated mantle-bound processes or all of these. Therefore, the institute pursues contemporary research in establishing the (i) amount and style of crustal deformation and uplift in the Himalaya using fluvial archives, (ii) reconstruction of high-resolution record of past climatic variations using peat, lakes, speleothems, ocean records, and dendrochronology, and (iii) hinterland-sink relationship through time.

\section{Theme 3: Earthquake Precursors Studies and Geohazard Evaluation}

Due to the plate movement along the Himalaya, the elastic strain energy is being built continually, the release of which results in earthquakes. The Indian part of the Himalaya has experienced four great earthquakes during the last century. However, no great earthquake has occurred in the Garhwal-Kumaun region during the recent period, leaving behind a seismic gap between the Kashmir-Himachal and Bihar-Nepal regions. We need to establish whether the seismic gap exists and if so, what will be its consequences. To identify the surface manifestation of past large earthquakes, which were enough to produce surface rupture along the Himalayan arc, paleo-earthquake studies that involve timing, size, and lateral extent of earthquake ruptures along the Himalayan frontal thrust fault need to be carried out. The paleo-seismic histories help to understand neotectonics, such as the regional patterns of seismicity and tectonic deformation, as well as the seismogenic behavior of specific faults. Further, it is necessary to evaluate the seismicity pattern by delineating subsurface structures and discontinuities pattern from seismological as well as other geophysical studies to mitigate the effects of a probable future earthquake. The dense broadband seismic (BBS) station network 
of WIHG in the NW Himalaya has made it feasible to investigate this along with the area-specific velocity structure using local, regional and teleseismic earthquakes.

Besides, the Himalayan region is undergoing sprout of developmental activities. Therefore, it is essential to carry out geo-engineering studies, including engineering geological mapping, rock mass classification, rock assessment for engineering purpose, landslide studies etc. for sustainable development.

\section{Theme 4: Biodiversity and Environmental Linkages}

Biodiversity comprises many plants, animals, and microbes that unite the atmosphere, geosphere and hydrosphere into one environmental system making it possible for millions of species including the humans. This has diversity within and among the fossil taxa and paleo-ecosystems. Numerous lines of evidence have established that life has changed through time, and explains its evolution. Signatures of past lives are found preserved in sediment archives. Major stratigraphical boundaries are delineated based on distinct biotic turnover events (extinctions and recoveries). Good understanding of paleo-diversity across the major boundaries (e.g., $\mathrm{PC} / \mathrm{C}, \mathrm{K} / \mathrm{T}, \mathrm{P} / \mathrm{E}$ etc.) and also pre- and post- India-Asia collision is important not only for stratigraphic correlation but also for the evolution of life and paleo-geographic reconstructions. The sedimentary records preserve the biodiversity-environment-paleogeography link at different time scales for Neoproterozoic-Cambrian and Cenozoic intervals. Himalaya is an excellent natural laboratory for testing the evolutionary hypotheses, diversification, extinction, recoveries, migrations and their linkages with changes in paleoenvironment and paleogeography. The scientific activities under this program involves (i) evolution of early life, (ii) understanding post-Gondwana drift of Indian plate, (iii) collision and pre-collision biotic and landscape reconstruction, food habits, and climatic change, (iv) biotic migration vis-a-vis uplift of the Himalaya, and (v) stratigraphy of sedimentary successions of the Himalaya.

\section{Theme 5: Himalayan Glaciers: Their Role in Indian Monsoon Variability and Geohydrological Changes in the Ganga Basin}

The Himalayan glaciers are vast and now have been termed as the Third Pole of the world. The fluctuations in the heat budget of the atmosphere may have a profound effect on the glacial advances and retreat, and hence on the Indian Monsoon. The glacial records are also essential to understand the changes in aerosol, greenhouse gas concentrations, and albedo variations. Since the sustained development of economically useful natural entities is an ecological and socio-cultural necessity, it is essential to understand the environment and processes which control and affect their occurrences. Therefore, the study on natural resources such as water (solid and liquid phases) and minerals are significant. Under the present scenario of global warming, the WIHG focuses on several studies: (i) component of glacial melt into the hydrological budget of the Himalayan river systems, (ii) high resolution in-situ hydrological investigations and laboratory data including conventional and isotopic tracers of water resources (groundwater, surface water, and precipitations), (iii) glacial movements and mass balance, (iv) paleo-glacial history and climate variability.

\section{Major Research Output}

\section{Theme 1: Geodynamic Evolution of the Himalaya and Adjoining Mountains}

The zircon $\mathrm{U}-\mathrm{Pb}$ ages and $\mathrm{Hf}$ isotopic compositions of felsic units of the Abor volcanic rocks (AVR) in the Eastern Himalayan Syntaxis, NE India, reveal the relationship between the AVR and the Kerguelen plume activity (Fig. 2). New geochemical and geochronological data show that the AVR was emplaced at the early stage ( $\sim 132 \mathrm{Ma})$ of eastern Gondwana breakup caused by the Kerguelen plume activity. They were emplaced in the continental rift tectonic setting. The depth of the magma source is confirmed near the spinel stability zone. The Abor volcanic rocks are positively comparable with other flood basalts that were formed by the outbreak of the Kerguelen plume. This study supports that the Kerguelen plume affected a large area of Eastern India, Western Australia and Antarctica during the early stage of the Gondwana breakup. 


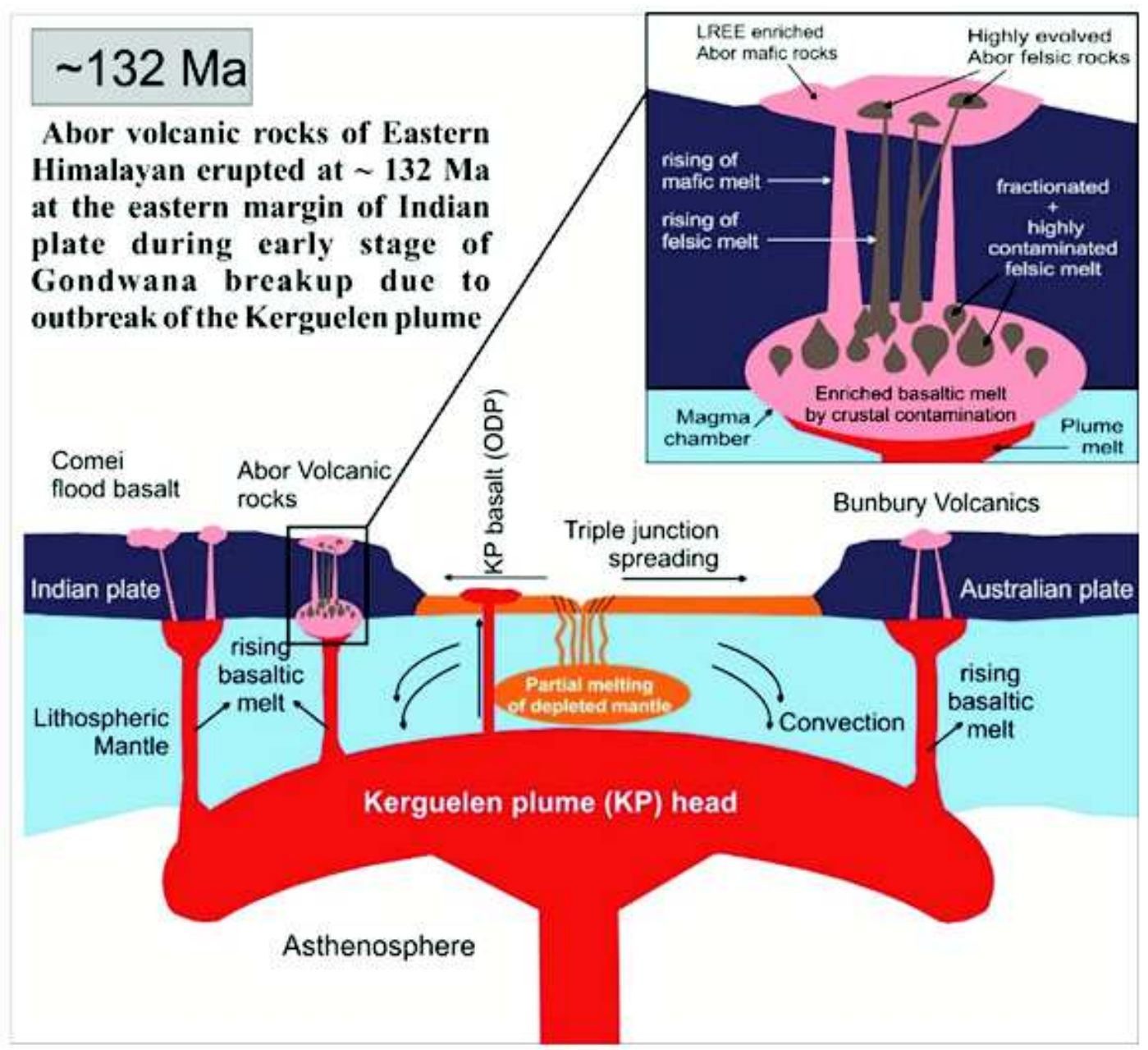

Fig. 2: Schematic model of tectono-magmatic evolution of Abor Volcanic Rockshaving linkage to the Kerguelen plume activity. Note the generation of Comei-Bunbury Large Igneous Province (LIP) magmatism ( 132 Ma) between the northeastern Greater India and south-western Australia

The study of ultramafic rocks from the base of the Ladakh ophiolite shows phase stability of betaolivine, derived from the mantle transition zone (410$660 \mathrm{~km})$. The transport mechanism is suggested via dunite channels along mantle adiabat in the focused convective flow below the spreading center. At the upward movement of the material from $>410 \mathrm{~km}$ depth, $\mathrm{C}-\mathrm{H}$ and $\mathrm{H}_{2}$ primary fluids precipitate diamond due to change in ambient redox condition. The peridotite hosted by dunite divulging the ultramafic nature at the basal part of Ophiolite in the suture zone complex retains the signature of mantle upwelling. This shows direct bearing on the collision dynamics of the Himalaya.

The Main Central Thrust Zone (MCTZ) in the Alaknanda valley, NW Himalaya, affected the Lesser
Himalayan Crystalline Sequence and has a gradual transition to the structurally overlying Higher Himalayan Crystalline Sequence (HHCS). Pseudo section modelling and garnet isopleth thermosbarometry of pelitic rocks yield peak metamorphic conditions of $6.3-7.5 \mathrm{kbar}$ and $550-582{ }^{\circ} \mathrm{C}$ in the MCTZ, and 8.0-10.0 kbar and $610-650^{\circ} \mathrm{C}$ in the basal part of the HHCS. The results indicate continuity in the P-T field gradient across the contact between the MCTZ and HHCS (Fig. 3). The observations are consistent with a recently proposed thermo mechanical model in which temperature in the shear zone rises due to viscous heating and pressure increases as a result of the weakening of the rocks.

Exhumation of P-T path of the sillimanite rocks in the Karakorum metamorphic complex has been 


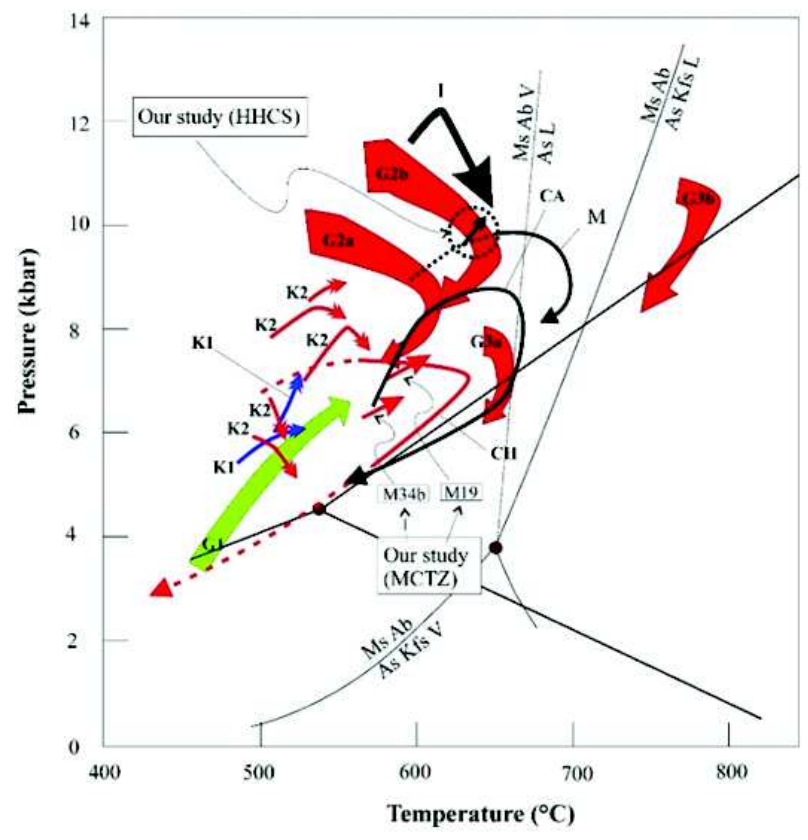

Fig. 3: The P-Tpaths of MCTZ and lower HHCS rocks in the Alaknanda valley, NW Himalaya (present study), and different sections of the Himalayas. G1 from LHS, G2a and G2b from MCTZ, G3a and G3b from HHCS eastern Nepal; K1 from lowermost MCTZ, K2 from lower and middle MCTZ - central Nepal; CH from LHCS, Sutlej valley - NW Himalaya; I from lower HHCS - far-eastern Nepal; CA from lower HHCS western Nepal; M from lower HHCS - central Nepal. For details see Thakur et al., (2015)

constrained from thermodynamic modeling, geothermobarometry, and fluid inclusions study. Metamorphic conditions for metapelites are shown by boxes (Fig. 4) and are compared with the study by others.

Talc deposits in the Deoban Formation of inner Lesser Himalaya in Kumaun were formed by lowgrade, regional burial metamorphism of the siliceous magnesium bearing carbonates consisting of magnesite and dolomite. The peak temperature of $300^{\circ}$ to $340^{\circ} \mathrm{C}$, pressure of 2 to $2.2 \mathrm{kbar}$ and a low $\mathrm{X}_{\mathrm{CO} 2}$ are estimated for the talc-magnesite assemblage. Lazulite, a phosphate mineral of ornamental importance, has been reported from the vicinity of a highly tectonized zone of the Main Central Thrust (MCT) in the Himalaya. The syntectonic growth of this lazulite with the Himalayan shearing occurred in a low salinity $\mathrm{H}_{2} \mathrm{O}-\mathrm{CO}_{2}$ metamorphic fluid regime with moderately enriched $\Delta \mathrm{D} \%$ o. The study also implies that this refractory mineral can sustain fluid inclusions within it against intense deformation

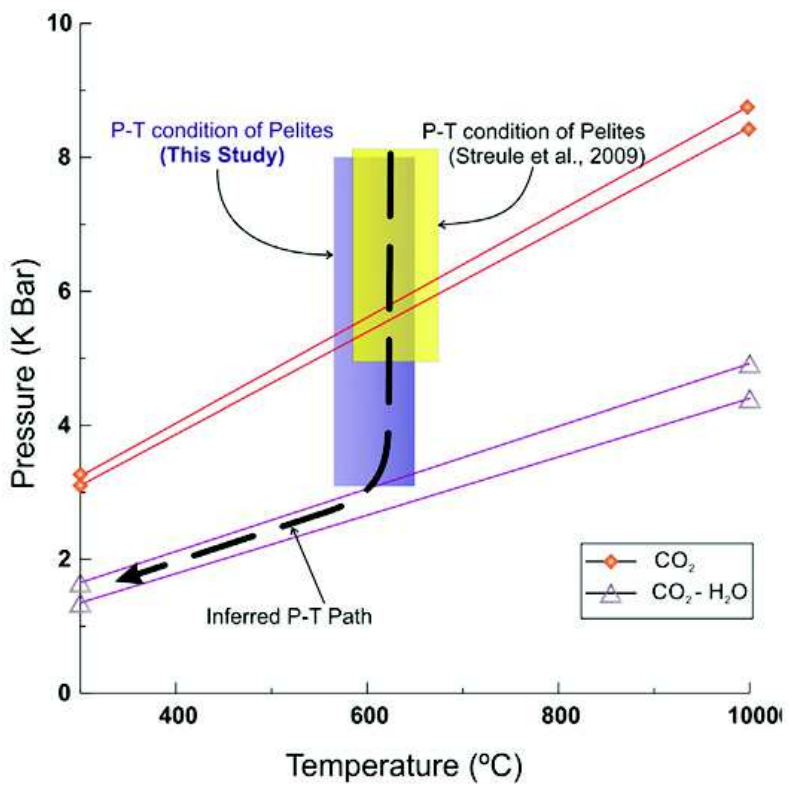

Fig. 4: The P-T condition of Pelites (present study) compared with the published research by others

conditions, such as in the MCT.

\section{Theme 2: Indian Monsoon-tectonic Interaction and Exhumation of the Himalaya}

Landscape evolution of the mountains responds to a continuum made by glacial-periglacial and foreland dynamics. These morphologic processes evolve with changing climate and tectonic configuration of the Himalayan fold and thrust belt. Accordingly, the past and present (i) major river systems like the Indus, the Brahmaputra, and the Ganga, (ii) large and small lakes covering the spectrum of climate and geomorphology of the Himalaya, and (iii) speleothem based climate records were studied. A model explaining the formation of fill and strath terraces implying the neotectonic evolution of the Himalaya was proposed and received a comprehensive global response. It suggested that the southern front of the Himalaya is following a critical taper wedge model with an outof-sequence deformation. The work also indicated that the high rate of river incision at NW Syntaxes might be controlling the riverine landscape on Ladakh. Further, the high resolution climate records, spanning over the Holocene, were generated using the peat, lakes and speleothems. Notably, a 35 ka speleothem record created from the Mawmluh cave of Meghalaya provided a first monsoon record from a continental archive suggesting a close correspondence between 

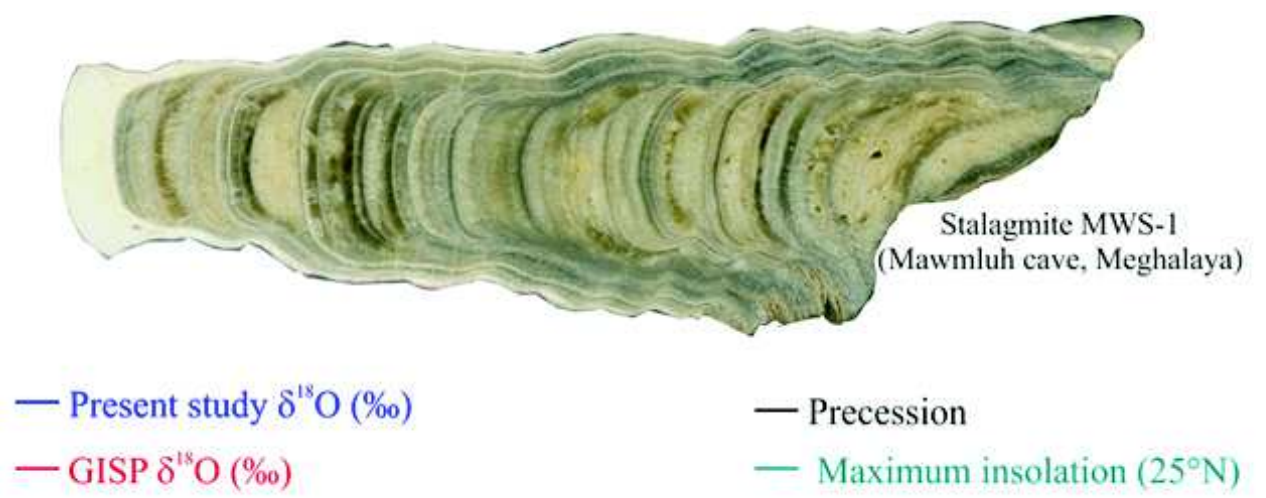

- Precession

- Maximum insolation $\left(25^{\circ} \mathrm{N}\right)$

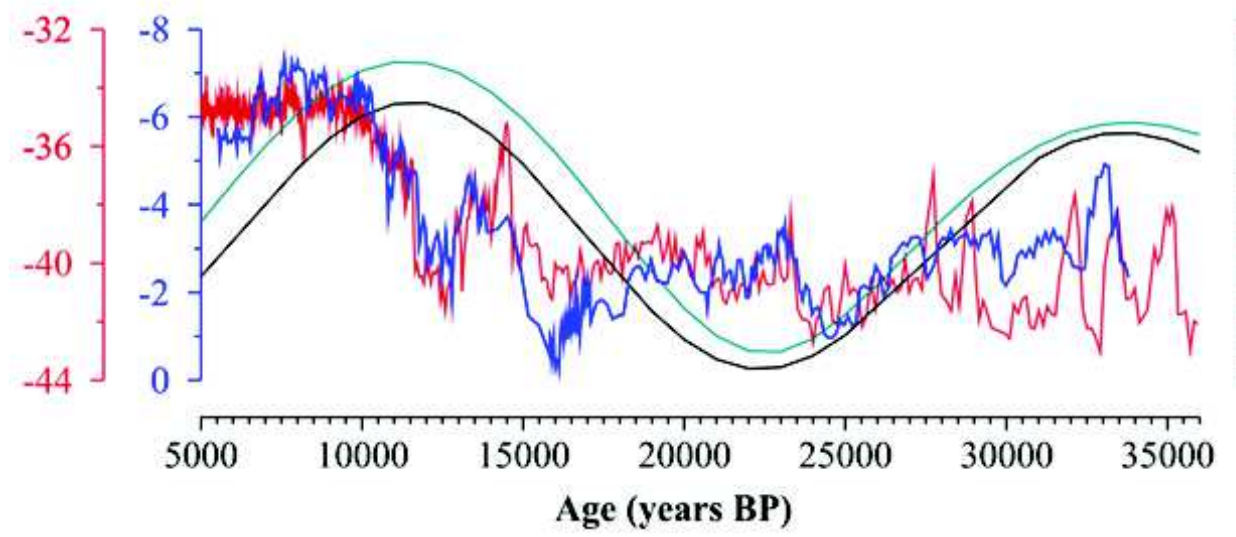

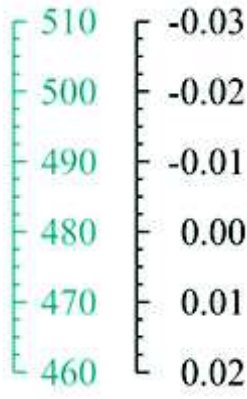

Fig. 5: $\delta^{18} \mathrm{O}$ proxy record of stalagmite. Indian summer monsoon variability (blue colour) using the stalagmite MWS-1 from the Mawmluh Cave, Meghalaya (Dutt et al., 2015) compared with that of the Greenland Ice Sheet Project 2 (GISP2) core $\delta^{180}$ data (red colour), maximum solar insolation at $25^{\circ} \mathrm{N}$ (cyan colour) and orbital precession (black colour) published by others

the variability in Solar Insolation and monsoon strength (Fig. 5).

\section{Theme 3: Earthquake Precursors Studies and Geohazard Evaluation}

The Main Himalayan Thrust (MHT) separating the downgoing Indian plate from the overriding Himalayan wedge is accountable for the occurrences of earthquakes in the Himalayan seismic belt. All mega thrust sheets of the Himalaya sole down at a depth to merge with the MHT. Thus, the MHT accumulates a substantial amount of elastic strain energy, which is released from time to time by several large and great earthquakes in the Himalaya. Most of these earthquakes occur at shallow depth coinciding with the mid-crustal ramp structure on the MHT. However, due to the paucity of high-resolution geophysical data, the geometry of MHT is poorly understood in large parts of the Himalaya. To investigate the geometry of MHT beneath Satluj valley in NW Himalaya, we carried out a passive seismic study based on receiver function (RF) analysis along with a NE-SW profile consisting of 18 seismological stations. The study reveals a gentle north dipping structure of the MHT (depth range $\sim 16$ to $27 \mathrm{~km}$ ) imaged between the Sub and Higher Himalaya in contrast to the reported ramp structure of the MHT beneath the Garhwal and Nepal Himalaya. The ramp structure is, however, identified further north, beyond the South Tibetan Detachment (STD) where the depth of MHT is $\sim 38 \mathrm{~km}$. This is significantly a different structure of the MHT beneath the Satluj valley, which is attributed to the effect of the under-thrusting of the Delhi-Hardwar Ridge (DHR). Conspicuously, no strong or massive earthquake is observed during 19642016 in this segment of the Himalayan Seismic Belt (HSB) indicating a relationship between the ramp structure of the MHT and the seismicity.The RF modelling and Common Conversion Point (CCP) 


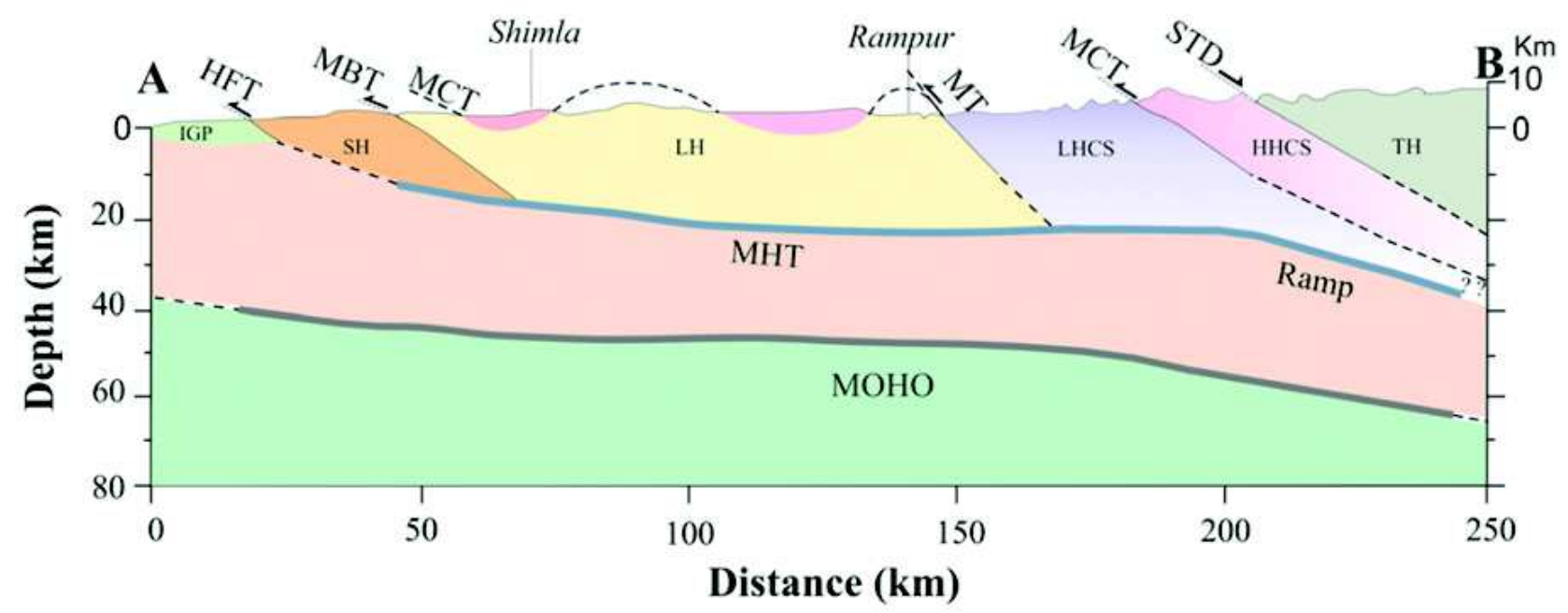

Fig. 6: Cross-section of litho-tectonic units - MHT and Moho from RF results along line A-B (Hazarika et al., 2017). The gently dipping MHT shows a ramp beyond the South Tibetan Detachment (STD). The Moho shows gradual dipping from south to north

stacking image of RFs show an increase of crustal thickness from $\sim 44 \mathrm{~km}$ near the Himalayan Frontal Thrust to $\sim 62 \mathrm{~km}$ in the Tethyan Himalaya. The geometry of Moho and MHT has been depicted in the following cross-section (Fig. 6).

Establishing the timing of past earthquakes along the CSG is critical in assessing regional seismic hazards for areas proximal to the HFT that have both large populations and vast properties. Further more, it is of particular interest due to an apparent longterm quiescence that advocates the potential for impending large-scale rupture. The paleoseismological studies from seven trench sites into a coherent OxCal age model for large-magnitude ruptures along the CSG indicate that the western half of the CSG probably ruptured during the historical event corresponding to an earthquake in $1344 \mathrm{CE}$.

The multi-proxy study provided the first evidence for 1950 A.D. primary surface faulting along the Himalayan Frontal Thrust (HFT), NE Himalaya at Pasighat. This suggests that great earthquakes accommodate the convergence between the southern Tibet and stable India along the MHT to the HFT. This study corroborates the first instance of using the post bomb radiogenic isotopes to help identify earthquake rupture. The surface ruptures of great earthquakes along the Himalaya arc and locations of paleo-seismological trenches are shown in Fig. 7.
The Himalaya is infested with numerous landslides and related mass movement, which are widely considered as the principal mass wasting agents in the valleys experiencing the varied influence of tectonics and climate. However, the pattern of landslides is rarely addressed in the literature that may act as the surface manifestation of the interrelationship among the tectonics, climate and lithology. Hence, the spatial distribution of landslides in the context of these was studied. It is observed that, in general, the length, width, area and volume of landslides increase while traversing from Lesser Himalaya to Higher Himalaya and the Tethyan Himalaya along the southwest to northeast transact, with an abrupt increase in dimensions near the hanging wall side of the Munsiyari Thrust and the Main Central Thrust (Fig. 8). This distinct change near these regional faults pertains to spatially varying litho-tectonics and climatic conditions, as this side receives high uplift and higher rainfall. The area-volume scaling relationship was also estimated and understood.

\section{Theme 4: Biodiversity and Environmental Linkages}

The Paleocene-Eocene Thermal Maximum (PETM), one of the most notable and widely documented global warming events in the geological history, occurred at the beginning of the Eocene ( $\sim 56 \mathrm{Ma})$, which caused substantial changes in the biota and geochemistry. It is marked worldwide by a negative isotopic excursion 


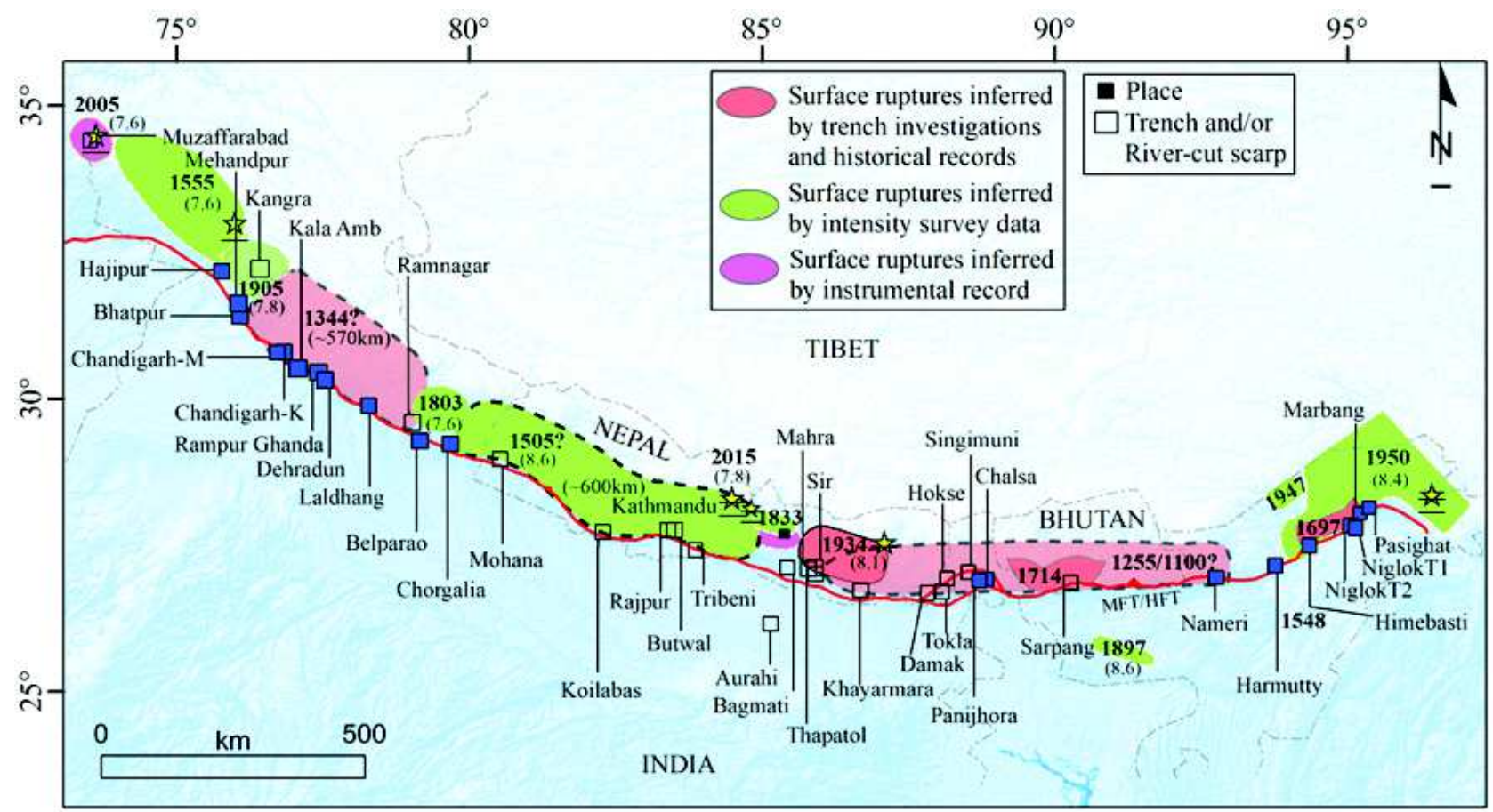

Fig. 7: A simplified map showing surface ruptures due to great earthquakes and locations of paleo-seismological trenches (Solid Blue square) excavated so far by WIHG along the Himalayan front. Surface rupture of CE 1344 (Jayangondaperumal et al., 2018) and CE 1697 (Priyanka, 2018; Pandey et al., 2019). Historical earthquakes were discovered through trench investigation along the Himalayan Frontal Thrust (see Jayangondaperumal et al., 2018 for further details)

of $\delta^{13} \mathrm{C}$, bloom of the dinoflagellate Apectodinium, turnover of larger foraminifera, diversification of planktic foraminifera, and carbonate dissolution of calcareous test shells, decrease in carbonates and increase in abundance of silicates and phyllosilicates, etc. There was a gap in identifying the PETM in the Himalaya even though some Himalayan sections are known to have Paleocene-Eocene transition beds. The basal part of the late Paleocene-middle Eocene Subathu Group, exposed at the village Kurla near Subathu in Himachal Pradesh (NW sub-Himalaya), was investigated for biotic, mineralogical, and geochemical signatures of this abrupt warming event. The results show carbon isotope excursion (CIE) of $3.4 \%$, the occurrence of index dinoflagellate genus Apectodinium, and carbonate dissolution of larger benthic foraminifera. The mineralogical changes across the Paleocene-Eocene transition exhibit an increase in quartz and phyllosilicates and a decrease in carbonates. The geochemical study shows (i) increase in $\mathrm{SiO} 2, \mathrm{~A} 12 \mathrm{O} 3, \mathrm{~K} 2 \mathrm{O}$ and $\mathrm{Fe} 2 \mathrm{O} 3$, (ii) reduction in $\mathrm{CaCO} 3$, (iii) decreasing trend of $\mathrm{Si} / \mathrm{Al}$, $\mathrm{Fe} / \mathrm{Al}$, and $\mathrm{Mg} / \mathrm{Al}$ ratios, (iv) increasing trend of $\mathrm{K} /$ $\mathrm{Al}, \mathrm{Ti} / \mathrm{Al}$, and $\mathrm{Zr} / \mathrm{Al}$ ratios, (v) changes in trace element abundance, (vi) maximum chemical index of alteration (CIA) of $85-89 \%$, and (vii) increase in abundance of rare earth elements (Fig. 9). The dataset mentioned above is very close to the PETM and even reflects its probable onset and peak phases. However, it is insufficient to identify the PETM in the studied section. Nevertheless, the study is the first attempt from a Himalayan section and brings out much new information.

\section{Theme 5: Himalayan Glaciers: Their Role in Indian Monsoon Variability and Hydrological Changes in the Ganga Basin}

Glaciers are most sensitive to climate change and therefore are important markers of climate fluctuation in space and time. Climate change has an increasing influence on the stability of the Himalayan glaciers that may affect the livelihood of mountain people. Deciphering the impact of climate change and a continuous melting of glaciers need to be understood for accurate estimation of ice volume changes and its response to the climate. In the Indian part of the Himalaya (IHR), there are $\sim 10,000$ glaciers. Our institute has been carrying out a detailed study on 


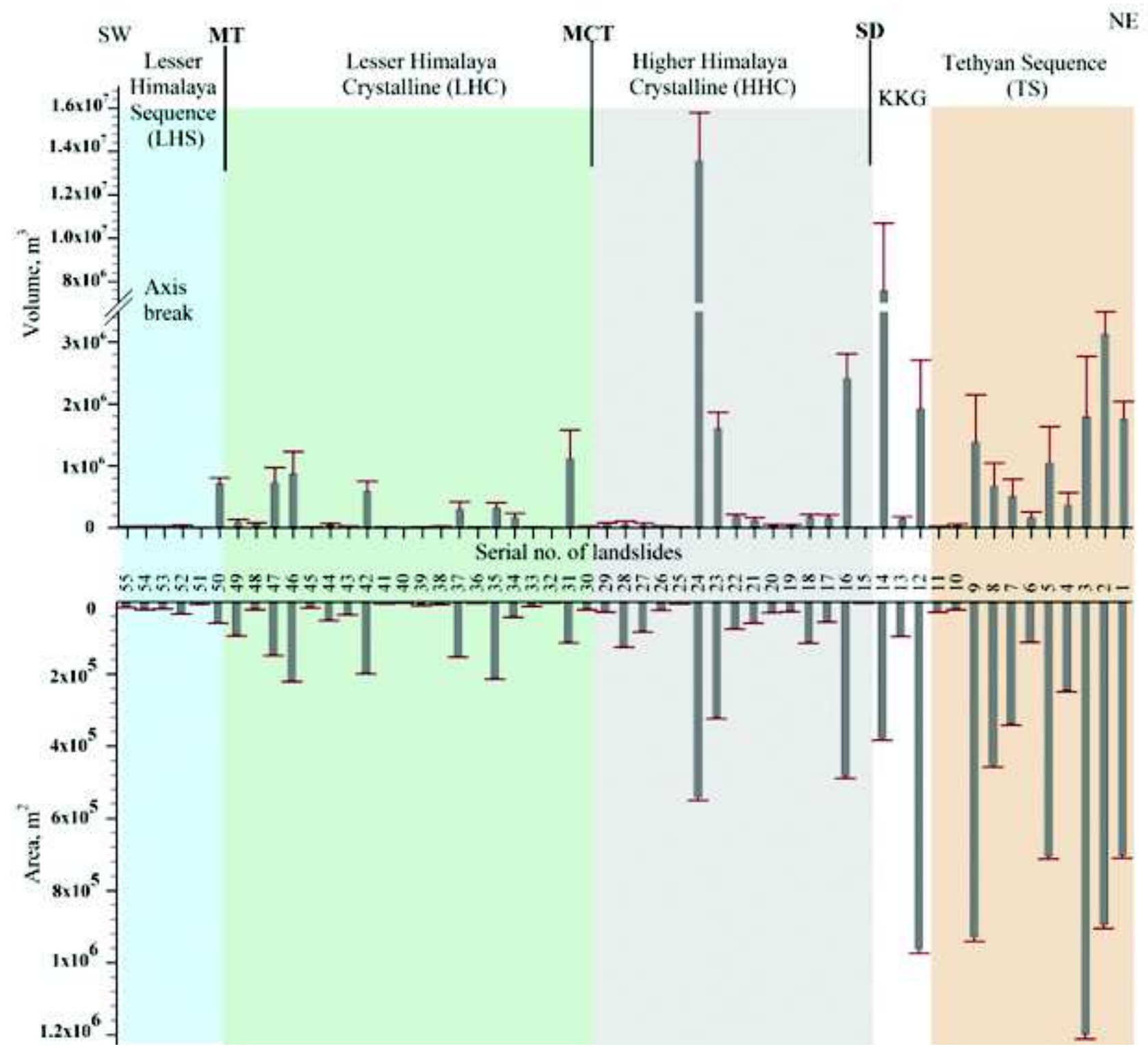

Fig. 8: Dimensional distribution of landslides from southwest to northeast in the Himalaya

several glaciers for the dynamic changes due to climate variability and the societal implications. The fluctuations in the heat budget of the atmosphere may have a profound effect on the glacial advances and retreats. Since the glaciers are perennial sources of freshwater, the study of natural water resources in the form of snow and ice, their dynamics and behavior due to the climate processes with space and time are critical. Under the present scenario of global warming, we have focused on (i) glacial mass balance and surface change, (ii) glacial meltwater \& hydrological budget, (iii) high resolution in-situ hydrological investigations and laboratory data including conventional and isotopic tracers of water resources (surface, sub-surface and precipitations) and (iv) glacial history and climate variability.

Dynamics of mass balance and its components carried out on several glaciers during the period 20152018, show negative mass balance in all the studied glaciers ranging between $-0.32 \mathrm{~m}$ and $-072 \mathrm{~m}$ w.e. $\mathrm{a}^{-1}$. Fig. 10 shows the mass balance of Chorabari glacier during the period 2016-2017. The continuous loss of glacier mass indicates that the melting is more than the snow accumulation. It is observed that there are not many differences in annual summer melting 


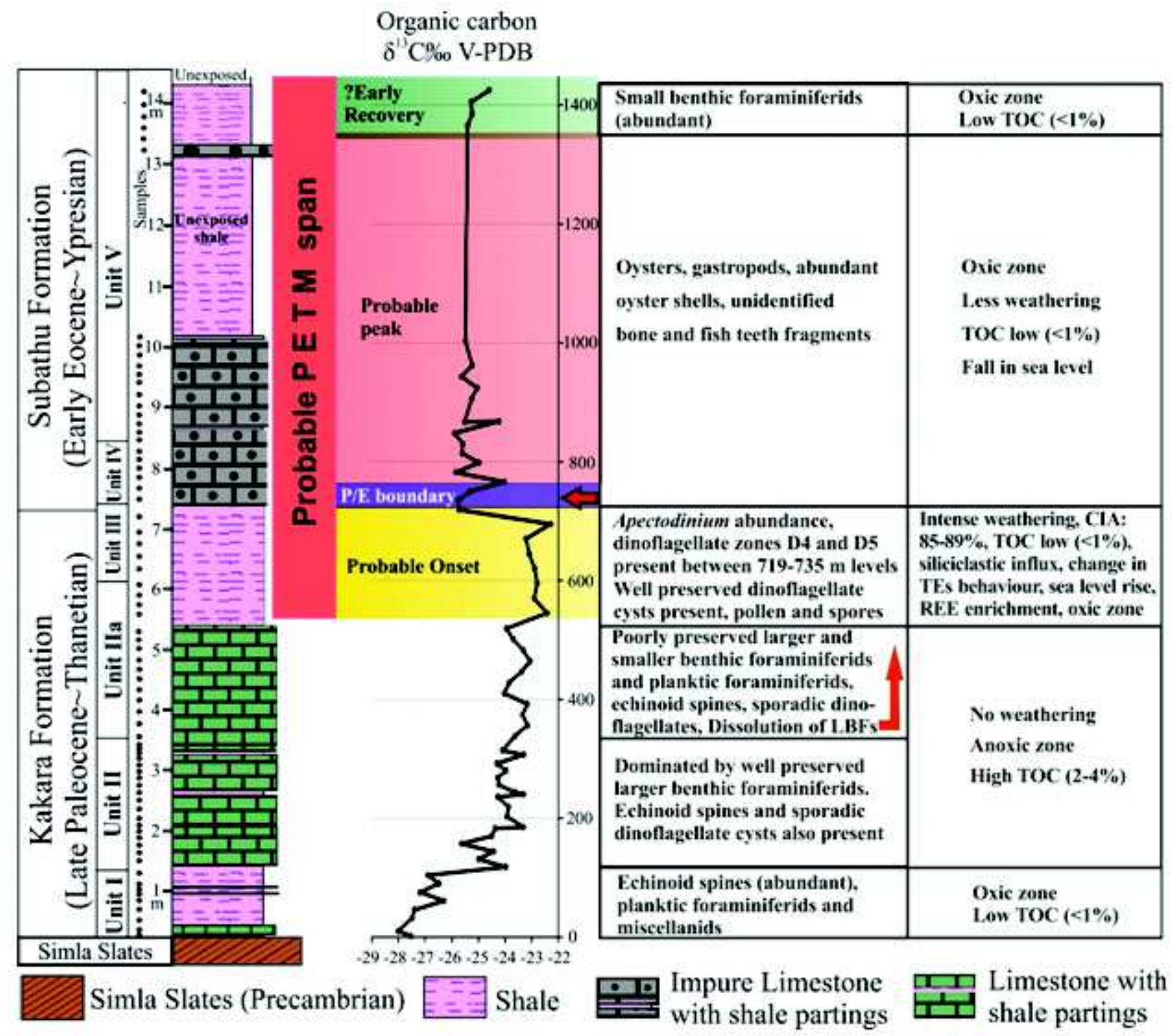

Fig. 9: The P/E boundary and various phases of the probable PETM span in the Subathu Group of the Kurla section, Delgi (Subathu), inferred using mainly geochemical and limited paleontological data

but winter snow accumulation varies from year to year. The net winter accumulation measured for the study period slightly decreases (1-2\%) compared to previous years as the Equilibrium Line Altitude (ELA) is ascendant. The ascending and descending of ELA or snow line also specifies the amount of snow cover during the period. The actual mass balance behavior based on tree-ring isotope fromDokriani glacier was also reconstructed, and the study shows a strong trend of negative mass balance since the late 1960s, which is also supported by current mass balance trend (Fig. $10 \mathrm{a}$ and $\mathrm{b})$.
Snout retreat is another critical component to determine the changes in length, aerial extent as well as altitudinal alteration of the glacier surface over the period. The changes in length of 18 glaciers in the upper Ganga basin in the central Himalayas from 1990 to 2017 were estimated using the satellite remote sensing data. The results indicate that the total glaciated area decreased from $313.34 \pm 7.95 \mathrm{~km}^{2}$ in 1994 to $306.36 \pm 8.04 \mathrm{~km}^{2}$ in 2015 , whereas retreat rates varied from $4.75 \pm 2.25$ to $28.25 \pm 2.25 \mathrm{~m} \mathrm{a}^{+1}$ with an average rate of $13.91 \pm 2.25 \mathrm{~m} \mathrm{a}^{+1}$ during this period (Fig. 10c). Further, it is also observed that the debris-covered area of each glacier increased from 


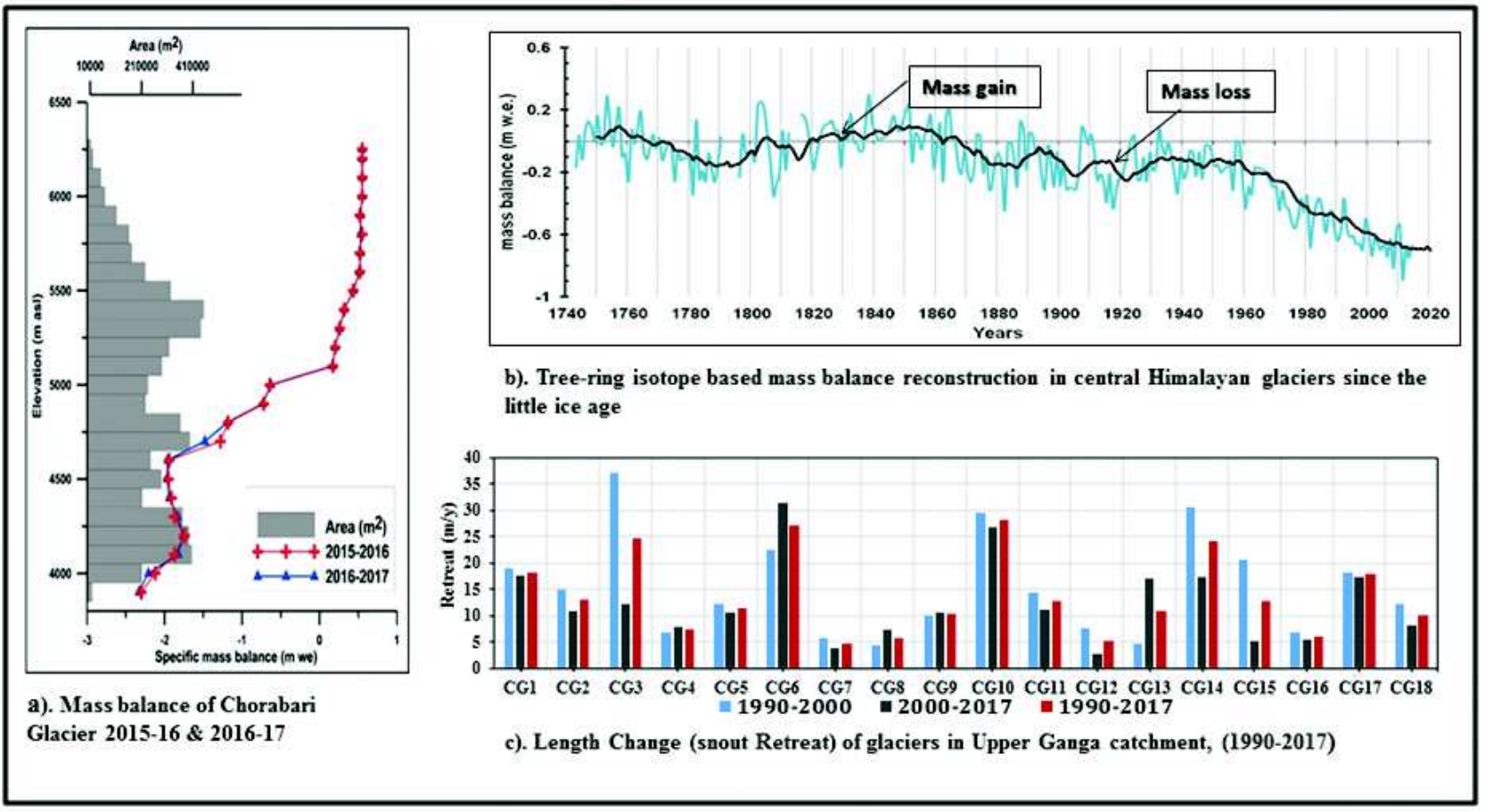

Fig. 10: Glacier mass balance trend (a and b) and terminus (snout) fluctuation (c) in the Upper Ganga Basin, Central Himalaya

$86.56 \pm 1.29$ to $97.99 \pm 1.75 \mathrm{~km}^{2}$ and the average snowline altitude ascended by $67 \mathrm{~m}$ during 1990-2017.

Meltwater discharge data were collected at the existing gauging site of studied glaciers during summer (May-October). The velocity area method was used to estimate the mean discharge in the river. The stagedischarge relationship for few glaciers has been developed to calculate discharge for the available water level records of 2014. The mean monthly discharge observed during the study period for different months showed fluctuating trend i.e. May, June, July, August, September and October are 1.1, $3.0,9.8,11.8,4.7$ and $2.2 \mathrm{~m}^{3} / \mathrm{s}$ respectively. The studies carried out so far in the IHR reveal that most of the studied glaciers are in the recession phase. However,

\section{Publications During 2015-2019}

1. Acharya S S, Panigrahi M K, Gupta A K and Tripathy S (2015) Response of trace metal redox proxies in continental shelf environment: Eastern Arabian Sea scenario Continental Shelf Research 106 70-84 the recession rate is highly heterogonous. Considering the current climatic trend, the glaciers in the region are likely to recede with an accelerated phase in the future. Hence, continuous, systematic and long term studies are required to monitor their response to climatic perturbations closely.

\section{Acknowledgments}

Prof. D M Banerjee and Prof. Sunil Bajpai are gratefully acknowledged for the invitation to write this report about WIHG in the PINSA Compendium. Special thanks are due to all staff of WIHG for generating the massive volume of data and information without which this report would not have been possible. Director, WIHG, is acknowledged for permission.
2. Acharya S S, Panigrahi M K, Kurian J, Gupta A K and Tripathy S (2016) Speciation of phosphorus in the continental shelf sediments in the Eastern Arabian Sea Continental Shelf Research 115 65-75

3. Adlakha V, Patel R C, Kumar A and Lal N (2018) Tectonic 
control over exhumation in the Arunachal Himalaya: new constraints from Apatite Fission Track Analysis Geol Soc London Sp Pub 481 SP 481.1

4. Agnihotri R, Dimri A P, Joshi H M, Verma N K, Sharma C, Singh J and Sundriyal Y P (2017) Assessing operative natural and anthropogenic forcing factors from long-term climate time series of Uttarakhand (India) in the backdrop of recurring extreme rainfall events over the northwest Himalaya Geomorphology 284 31-40

5. Agrawal S, Srivastava P, Meena N K, Rai S, Bhushan R, Misra D K and Gupta A K (2015) Stable (ä13C and ä15N) isotopes and Magnetic Susceptibility record of late Holocene climate change from a lake profile of the northeast Himalaya Journal of Geological Society of India 86 696705

6. Ahluwalia Rajeev S, Rai S P, Gupta A K, Dobhal D P, Tewari Kamal Reet and Garg P K (2016) Towards the understanding of the flash flood through isotope approach in Kedarnath valley in June 2013, Central Himalaya, India Natural Hazards 82 321-332

7. Ahmad R, Chauhan P and Srivastava S K (2018) Groundwater study in eastern Dehradun valley and adjoining areas using remote sensing and GIS observations, Himalayan Geology 39 212-222

8. Ali, Shukla A and Romshoo S A (2017) Assessing linkages between spatial facies changes and dimensional variations of glaciers in the upper Indus Basin, western Himalaya Geomorphology 284 115-129

9. Arun Prasath R, Paul Ajay and Singh Sandeep (2017) Upper crustal stress and seismotectonic of the Garhwal Himalaya using small-to-moderate earthquakes: Implications to the local structures and free fluids Journal of Asian Earth Sciences 135 198-211

10. Asthana A K L, Gupta A K, Luirei K, Bartarya S K, Rai S K and Tiwari S K (2015) A Quantitative Analysis of the Ramganga Drainage basin and structural control on drainage pattern in the fault zones, Uttarakhand Journal of Geological Society of India 86 9-22

11. Asthana A K L, Luirei K, Kothyari G and Pandey P(2018) Quantitative analysis of the relative tectonic activity in the Nayar River Basin, Garhwal Outer Lesser Himalaya, through the application of morphometric indices Himalayan Geology 39 57-62

12. Basak B, Srivastava P, DasguptaS, Kumar A and Rajaguru S N (2015) Earliest Dates and implications of Microlithic industries of Late Pleistocene from Mahadebbera and Kana, Purulia District, West Bengal Current Science 107 11671171
13. Basak B and Srivastava P (2017) Earliest Dates of Microlithic Industries (42-25 ka) from West Bengal, Eastern India: New Light on Modern Human Occupation in the Indian Subcontinent Asian Perspectives 56 237-59

14. Bhakuni S S and Luirei K (2016) Normal faults near the top of the footwall of Ramgarh Thrust along Kosi River valley, Kumaun Lesser Himalaya Current Science 110 640648

15. Bhakuni S S and Luirei K (2016) Soft-sediment deformation structures in Middle Siwalik rocks near south of Main Boundary Thrust of SE Kumaun Sub Himalaya, Nainital district, Uttarakhand Himalayan Geology 37 153-164

16. Bhakuni S S, Luirei K, Kothyari G Ch. and Imsong W (2017) Transverse tectonic structural elements across Himalayan mountain front, eastern Arunachal Himalaya, India: Implication of superposed landform development on analysis of neotectonics Geomorphology 282 176-194

17. Bhambri R, Hewitt K, Kawishwar P and Pratap B (2017) Surge-type and surge- modified glaciers in the Karakoram Scientific Reports 715391

18. Bhambri R, Mehta M, Singh S, Jayangondaperumal R, Gupta A K, and Srivastava P (2017) Landslide inventory and damage assessment in the Bhagirathi Valley, Uttarakhand, during June 2013 flood Himalayan Geology 38 193-205

19. Bhambri R, Mehta M, Dobhal D P, Gupta A K, Pratap Bhanu, Kesarwani, Kapil and Verma, Akshaya (2016) Devastation in the Kedarnath (Mandakini) Valley, Garhwal Himalaya during June 16-17, 2013: A remote sensing and ground-based assessment Natural Hazard 80 1801-1822

20. Bhambri R, Mishra A, Kumar A, Gupta A K, Verma A and Tiwari S K (2018) Glacier Lake inventory of Himachal Pradesh Himalayan Geology 39 1-32

21. Bhattacharya A R, Bose S, Mukherjee Barun K, Mamtani, MA and Srivastava D C (2016) Soft-sediment deformation structures in Middle Siwalik rocks near south of Main Boundary Thrust of SE Kumaun Sub Himalaya, Nainital district, Uttarakhand Proc Indian National Science AcademyJuly Spl Issu 82 435-443

22. Bikramaditya R K, Singh A K, Sen K and Sangode S J (2017) Detection of a weak late-stage deformation event in granitic gneiss through anisotropy of magnetic susceptibility: implications for the tectonic evolution of the Bomdila Gneiss in the Arunachal Lesser Himalaya, Northeast India Geological Magazine 154 476-490

23. Bohra A and Kotlia B S (2015) Tectono-climatic signatures during the Late Quaternary in the Yunam Basin, Baralacha Pass (Upper Lahaul Valley, India), derived from multi- 
proxy records Quaternary International 371 111-121

24. Bohra A (2016) Applications of CRN dating technique with reference to Indian Himalaya: A Compilation Himalayan Geology 37 54-66

25. Bora D K, Hazarika D, Paul A, Borah K and Borgohain J M (2018) Shear wave splitting and crustal anisotropy in the Shillong-Mikir plateau of Northeast India Pure and Applied Geophysics 175 243-255

26. Bora D K, HazarikaD, Paul A, Borah K and Borgohain J M (2018) Shear wave splitting and crustal anisotropy in the Shillong-Mikir plateau of Northeast India Pure and Applied Geophysics 175 243-255

27. Chand P, Sharma M C, Bhambri R, Sangewar C V and Juyal N (2017) Reconstructing the pattern of the Bara Shigri Glacier fluctuation since the end of the Little Ice Age, Chandra valley, north-western Himalaya Progress in Physical Geography 41 643-675

28. Chaudhary S, Shukla U K, Sundriyal Y P, Srivastava P and Jalal Poonam (2015) Formation of paleovalleys in the Central Himalaya during the valley aggradation Quaternary International 371 254-267

29. Chauhan D S, Sharma R and Kumar S (2017) Hydrogeochemistry, stable isotope study and implication for the origin of geothermal springs in Northeast Kumaun Himalaya, India Himalayan Geology 38 129-140

30. Chauhan G S, Nainwal H C and Gupta V (2018) Stability analysis of rock-cut slopes along the Minas road between Ichhari Dam and Minas Bridge, Tons valley, Garhwal Himalaya Himalayan Geology 39 68-84

31. Chauhan P, Chauniyal D D, Singh Nilendu and Tiwari Reet Kamal (2016) Quantitative geo-morphometric and land cover-based micro-watershed prioritization in the Tons river basin of the lesser Himalaya Environmental Earth Sciences 75 1-17

32. Chauhan P, Singh N, Chauniyal D D, Ahluwalia R S and Singhal M (2016) Differential behavior of a Lesser Himalayan watershed in extreme rainfall regimes Journal of Earth System Science 126 1-13

33. Chauhan V, Khandelwal D D and Kumar N (2016) A comparative study of gravity and crustal deformation data through Superconducting Gravimeter and GPS in the North-West Himalayan region Episodes 39 599-603

34. Choudhury S, Asthana A K L, Luirei K, Srivastava P, Bartarya S K, Sundriyal Y P, Arya P and Kulkarni S (2017) Geomorphic evolution of a non-glaciated river catchment in Lesser Himalaya: Response to tectonics Quaternary International 462 211-225
35. Das S, Basu A and Mukherjee B K (2017) In-situ peridotitic diamond in Indus ophiolite sourced from hydrocarbon fluids in the mantle transition zone Geology 45 755-758

36. Das S, MukherjeeB K, Basu A R and Sen K (2015) Peridotitic minerals of the Nidar Ophiolite in the NW Himalaya: sourced from the depth of mantle transition zone and above Geological Society of London 412 271286

37. Deep A, Pandey Chhavi P, Nandan H and Purohit K D (2017) Analysis of air pollutants in Rishikesh and Dehradun city of Uttarakhand: Influence of surface meteorological parameters J Env Bio-Sci 31 459-462

38. Deswal S, Sharma M C, Saini R, Chand P, Juyal N, Singh I, Srivastava P and Bahuguna I M (2017) Late Holocene Glacier Dynamics in the Miyar Basin, Lahaul Himalaya, India Geosciences $\mathbf{4 7} 64$

39. Dey J, Jayangondaperumal R, Sarkar S and Bhowmik A (2017) Geometric tests and their application to fault-related folds in NW Himalayan Foreland Thrust belt of India Journalof Earth Science System 126 1-17

40. Dobhal D P and Pratap B (2015) Variable Response of Glaciers to Climate Change in Uttarakhand Himalaya, India. In: Joshi et al. (ed.), Dynamics of Climate Change and Water Resources of Northwestern Himalaya. Springer International Publishing Switzerland Society of Earth Scientists Series 141-150

41. Dosseto A, May J H, Choi J H, Swander Z J, Fink D, Korup O, Hesse P, Singh T, Mifsud C and Srivastava P (2018) Late quaternary fluvial incision and aggradation in the Lesser Himalaya, India Quaternary Science Reviews $197112-28$

42. Dosseto A, Vigier N, Joannes-Boyau R, Moffat I, Singh T and Srivastava P (2015) Rapid response of silicate weathering rates to climate change in the Himalaya Geochemical Perspectives Letters 1 10-19

43. Dunn R, Rose K D, Rana R S, Kumar K, Sahni A and Smith T (2016) New primate postcrania from the Early Eocene of Gujarat, India, and the Strepsirrhine-Haplorhine divergence Journal of Human Evolution 99 25-51

44. Dutt S, Gupta A K, Bernd Wünnemann and Dada Yan (2018) A long arid interlude in the Indian summer monsoon during 4,350 to 3,450 cal. yr BP contemporaneous to the displacement of the Indus valley civilization Quaternary International 482 83-92

45. Dutt S, Gupta A K, Clemens S C, Cheng H, Singh R K, Kathayat G and Edwards R L (2015) Abrupt changes in Indian Summer Monsoon strength during 33,800 to 5500 years B.P., Geophysical Research Letters 42 5526-5532 
46. Dutt S, Gupta A K, Singh M, SonuJaglan, P Saravanan, P Balachandran and Singh A (2019) Climate variability and evolution of the Indus civilization Quaternary International 507 15-23

47. Ganguly S, Tiwari S, Bhan U, Mittal S and Rai S (2015) Melting of Sea Ice Inexplicable for Recent Global Eustatic Sea Level Rise Journal of Earth Science and Climate Change 6245

48. Garg P K, Meena N K and Mahajan A K (2018) Hydrochemistry and Water Quality of Rewalsar Lake of Lesser Himalaya, Himachal Pradesh India Environmental Monitoring and Assessment 19084

49. Garg P K, Shukla A and Jasrotia A S (2017) Influence of topography on glacier changes in the central Himalaya, India Global and Planetary Change 155 196-212

50. Garg P K, Shukla A, Tiwari R K and Jasrotia A S (2017) Assessing the status of glaciers in part of the Chandra basin, Himachal Himalaya: A multiparametric approach Geomorphology 284 99-114

51. Garg S, Shukla A, Mehta M, Kumar V, Samuel S A, Bartarya S K and Shukla U K (2018) Field evidence showing rapid frontal degeneration of the Kangriz glacier, western Himalayas, Jammu \& Kashmir Journal of Mountain Science 5 1199-1208

52. Gautam PK and Biswas A(2017) 2D Geo-electrical imaging for shallow depth investigation in Doon Valley SubHimalaya, Uttarakhand India Journal of Model Earth Syst Environ 3 441-449

53. Gautam P K, Arora S, Kannaujiya S, Singh A, Goswami A and Champatiray P K (2017) A comparative appraisal of groundwater resources using GRACE-GPS data in highly urbanized regions of Uttar Pradesh, India Journal of Sustain Water Resource Management 3 441-449

54. Gautam P K, Chauhan V, Sathyaseelan R, Kumar N, John $\mathrm{P}$ and Pappachen (2018) Co-seismic ionospheric GPSTEC disturbances from different source characteristic earthquakes in the Himalaya and the adjoining regions NRIAG Journal of Astronomy \& Geophysics 7 237-246

55. Gautam P K, Gahalaut V K, Prajapati S K, Kumar N, Yadav R K, Rana N and C P Dabral (2017) Continuous GPS measurements of crustal deformation in GarhwalKumaun Himalaya Quaternary International 462 124-129

56. Gautam P K R and Biswas A (2016) 2D Geo-electrical imaging for shallow depth investigation in Doon Valley Sub-Himalaya, Uttarakhand, India Modeling Earth System Environment 2175 (DOI 10.1007/s40808-016-0225-4)

57. Ghosh R, Sehgal R K, Srivastava P, Shukla U K, Nanda A C and Singh D S (2016) Discovery of Elephas cf. namadicus from the Late Pleistocene Strata of Marginal Ganga Plain Journal of Geological Society of India 88 559-568

58. Ghosh R, Srivastava P, Shukla U K, Singh I, Champati Ray P K and Sehgal R K (2018) Tectonic forcing of evolution and Holocene erosion rate of ravines in the Marginal Ganga Plain, India Journal of Asian Earth Sciences 162 137-147

59. Goyat M S, Jaglan V, Tomar V, Louchaert G, Kumar A, Kumar K, Singla A, Gupta R, Bhan U, Rai S K and Sharma $S$ (2017) Superior thermomechanical and wetting properties of ultrasonic dual-mode mixing assisted epoxy-CNT nanocomposites High Performance Polymers 20 1-11

60. Groppo C, Rolfo F, Sachan H K and Rai S K (2016) Petrology of blueschist from the Western Himalaya (Ladakh, NW India): Exploring the complex behavior of a lawsonite-bearing system in a paleo-accretionary setting Lithos 252-253 41-56

61. Gupta A K, Yuvaraja A, Prakasam M, Clemens S C and Velu A (2015) Evolution of the South Asian monsoon wind system since the late Middle Miocene Palaeogeography, Palaeoclimatology, Palaeoecology 438 160-167

62. Gupta S and Kumar K (2015) Early Eocene rodents (Mammalia) from the Subathu Formation of type area (Himachal Pradesh), NW sub-Himalaya, India: Palaeobiogeographic implications Journal of Earth System Science 124 1201-1221

63. Gupta S and Kumar K (2019) Precursors of the PaleoceneEocene Thermal Maximum (PETM) in the Subathu Group, NW sub-Himalaya, India Journal of Asian Earth Sciences $16921-46$

64. Gupta V and Sharma Ruchika (2015) Kinematic Rockfall Hazard Assessment along a Transportation Corridor in the Upper Alaknanda valley, Garhwal Himalaya, India Bulletin of Engineering Geology and Environment 74315326

65. Gupta V, Bhasin R K, Kaynia A M, Tandon R S and Venkateshwarlu B (2016) Landslide hazard in the Nainital Township, Kumaun Himalaya, India - the case of Sept 2014 landslide in Nainital, Kumaun Himalaya Natural Hazards 80 863-877

66. Gupta V, Bhasin R K, Kaynia A M, Kumar V, Saini A S, Tandon R S and Pabst T (2016) Finite Element Analysis of failed slope by Shear Strength Reduction technique: a case study for Surabhi Resort Landslide, Mussoorie township, Garhwal Himalaya Geomatics Natural Hazards and Risk 7 1677-1690

67. Gupta V, Jamir I, Kumar V and Devi M (2017) Geomechanical characterization of slopes for assessing 
rockfall hazards between Janki Chatti and Yamunotri Temple, Yamuna valley, Higher Himalaya, India Himalayan Geology 38 156-170

68. Gupta V, Mahajan A K and Thakur V C (2015) A study on landslides triggered during Sikkim Earthquake of September 18, 2011 Himalayan Geology 36 81-90

69. Gupta V, Nautiyal Hemlata, Kumar V, Jamir I and Tandon R S (2016) Landslide hazards around Uttarkashi township, Garhwal Himalaya after the tragic flash flood in June 2013 Natural Hazards 80 1689-1707

70. Gupta V, Tandon R S, Venkateshwarlu B, Bhasin R K and Kaynia A M (2017) Accelerated mass movement activities due to increased rainfall in the Nainital township, Kumaun Lesser Himalaya, India Zeitschrift fur Geomorphologies $6129-42$

71. Hajra S, Hazarika D, Bankhwal M, Kundu A and Kumar N (2019) Average crustal thickness and Poisson's ratio beneath the Kali River Valley, Kumaun Himalaya, Journal of Asian Earth Sciences 173 176-188

72. Hazarika D, Hajra S, Bankhwal M, Verma S, Yadav D K and Kumar N (2018) Crustal structure beneath Multiparametric Geophysical Observatory at Ghuttu, Garhwal Himalaya Himalayan Geology 39 233-241

73. Hazarika D, Paul A, Wadhwan M, Kumar N, Sen K and Pant C C (2017) Seismotectonics of the Trans-Himalaya, Eastern Ladakh, India Constraints from moment tensor solutions of local earthquake data Tectonophysics 69838 46

74. Hazarika D, Wadhawan M, Paul A, Kumar N and Borah K (2017) Geometry of the Main Himalayan Thrust and Moho beneath Satluj valley, Northwest Himalaya: constraints from receiver function analysis Journal of Geophysical Research, Solid Earth 122 2929-2945

75. Imsong W, Choudhury S and Phukan S (2016) Ascertaining the neotectonic activities in the southern part of Shillong Plateau through geomorphic parameters and remote sensing data, Current Science 110 91-98

76. Jain A K, Dasgupta S, Bhargava O N, Israil M D, Jayangondaperumal R, Patel R C, Mukul M, Parcha S K, Adlakha V, Agarwal K K, Singh P, Bhattacharyya K and Pant N C (2016) Tectonics and Evolution of the Himalaya,Proc.Indian National Science Academy 82 581604

77. Jamir I, Gupta V, Kumar V and Thong G T (2018) Evaluation of Potential Surface Instability in Kharsali Village, Yamuna Valley, NW Himalaya Journal of Mountain Science 14 1666-1676

78. Jayangondaperumal R, Devrani U and Dubey A K (2015)
Petrofabric and magnetic strains in the Garhwal Himalaya: A comparative study in the region of superimposed folding Himalayan Geology 36 39-47

79. Jayangondaperumal R, Kumahara Y, Thakur V C, Kumar A, Srivastava P, Dubey Shubhanshu, Joevivek V and Dubey AK (2017) Great earthquake surface ruptures along with backthrust of the Janauri anticline, NW Himalaya Journal of Asian Earth Sciences 133 89-101

80. Jayangondaperumal R, Niemi M and Kumar N (2017) Earthquakes and active tectonics of the Himalayan convergent boundary Quaternary International 462 1-2

81. Jayangondaperumal R, Robyn L, Daniels Tina and Niemi M (2017) A paleoseismic age model for large-magnitude earthquakes on fault segments of the Himalayan Frontal Thrust in the Central Seismic Gap of northern India Quaternary International 462 130-137

82. Joevivek V, Chandrasekar $\mathrm{N}$ and Jayangondaperumal $\mathrm{R}$ (2016) Evaluation of optimal wavelet filters for seismic wave analysis Himalayan Geology 37 176-189

83. Joshi H and Tiwari Meera (2016) Tianzhushaniaspinosa and other large acanthomorphicacritarchs of Ediacaran Period from the Infrakrol Formation, Lesser Himalaya, India Precambrian Research 287 325-336

84. Jowhar T N (2015) P-T paths from the Gibbs method and its applications. In: Shrivastava K L and Srivastava P K (eds.), Frontiers of Earth Science Scientific Publishers (India) 457-463

85. Karakoti I, Kesarwani K, Mehta M and Dobhal D P (2016) Extended T-index models for glacier surface melting: a case studyfrom Chorabari Glacier, Central Himalaya, India Theoretical and Applied Climatology 126 401-410

86. Karakoti I, Kesarwani K, Mehta M and Dobhal D P (2017) Modelling of meteorological parameters for the Chorabari Glacier valley, Central Himalaya, India Current Science 112 1553-1560

87. Kesarwani K, Dobhal D P, Durgapal A and Mehta M (2015) Prevailing meteorological conditions and cloud cover estimation during the ablation season of the Chorabari Glacier, Central Himalaya, India Himalayan Geology 36 $134-142$

88. Khan Z, Ahmad A H M, Sachan H K and Quasim M A (2018) The effects of diagenesis on the reservoir characters in Ridge Sandstone of Jurassic Jumara Dome, Kachchh, Western India Journal of the Geological Society of India 92 145-156

89. Khandelwal D D, Gupta A K and Chauhan V (2015) Observations of rainfall in Garhwal Himalaya, India during 2008-2013 and its correlation with TRMM data Current 
Science 108 1146-1151

90. Kharya A, Sachan H K, Tiwari S K, Singhal S, Singh P C, Rai S K, Kumar S, Mehta M and Gautam P K R (2016) New occurrence of Albitite from Nubra valley, Ladakh: Characterization from mineralogy and whole-rock geochemistry Current Science 11 1531-1535

91. Koenigswald W V, Rose K D, Holbrook L T, Kumar K, Rana R S, and Smith T (2018) Mastication and enamel microstructure in Cambaytherium, a perissodactyl-like Ungulate from the early Eocene of India Paläontologisches Zeitschrift 92 671-680

92. Kothyari G C and Luirei K (2016) Late Quaternary tectonics and fluvial aggradation in a monsoon dominated Saryu River valley: Central Kumaun Himalaya Geomorphology 268 159-176

93. Kothyari G C, Kandregula R S and Luirei K (2017) Response: Discussion of 'Morphotectonic records of neotectonic activity in the vicinity of North Almora Thrust Zone, Central Kumaun Himalaya Geomorphology 301 153-166

94. Kothyari G C, Kandregula R S and Luirei K (2017) Morphotectonic records of neotectonic activity in the vicinity of North Almora Thrust Zone, Central Kumaun Himalaya Geomorphology 285 272-286

95. Kotla S S, Patnaik R, Sehgal R K and Kharya A (2018) Isotopic evidence for ecological and climate change in the richly fossiliferous Plio-Pleistocene Upper Siwalik deposits exposed around Chandigarh, India Journal of Asian Earth Sciences 163 32-42

96. Kumar V, Gupta V, and Jamir I(2018) Hazard Evaluation of Progressive Pawari Landslide Zone, Satluj Valley, Higher Himalaya, India Natural Hazards 93 1029-1047

97. Kumar A and Srivastava P (2017) The role of climate and tectonics in aggradation and incision of the Indus River in the Ladakh Himalaya during the late Quaternary Quaternary Research 87 363-385

98. Kumar A and Srivastava P (2018) Landscape of the Indus River. In: Singh, D.S. (ed.), The Indian Rivers: Scientific and Socio-Economic aspects. Springer, Singapore Springer Nature Singapore Pte Ltd (https://doi.org/10.1007/978981-10-2984-4_4)

99. Kumar A, Asthana A K L and Rao Singh Priyanka, Jayangondaperumal R, Gupta A K, Bhakuni S S (2017) Assessment of landslide hazards induced by extreme rainfall event in Jammu and Kashmir Himalaya, northwest India Geomorphology 284 72-87

100. Kumar A, Gupta A K, Bhambri R, Verma A, Tiwari S K and Asthana A K L (2018) Assessment and review of hydrometeorological aspects for cloudburst and flash flood events in the third pole region (Indian Himalaya) Polar Science 18 5-20

101. Kumar A, Kumar N and Mukhopadhyay S (2018) Investigation of azimuthal variation in seismic surface waves group velocity in the western part of HimalayaTibet and Indo-Gangetic plains region Himalayan Geology 39 33-46

102. Kumar A, Kumar N, Mukhopadhyay S and P Vaidya (2017) Crustal and uppermost mantle structures in the frontal Himalaya and Indo-Gangetic basin using surface wave: Tectonic implications Quaternary International 462 3449

103. Kumar A, Mukhopadhyay S, Kumar N and Baidya P R (2018) Lateral Variation in Crustal and Mantle Structure in the Bay of Bengal Based on Surface Wave Data Journal of Geodynamics 113 32-42

104. Kumar A, Srivastava P and Meena N K (2017) Late Pleistocene aeolian activity in the cold desert of Ladakh: a record from sand ramps Quaternary International 443 1328

105. Kumar A, Tiwari S K, Verma A and Gupta A K (2018) Tracing isotopic signatures ( $\mathrm{a} \mathrm{D}$ and $\mathrm{a} 18 \mathrm{O}$ ) in precipitation and glacier melt over Chorabari Glacier-Hydroclimatic inferences for the Upper Ganga Basin (UGB), Garhwal Himalaya Journal of Hydrology (Regional Studies) 15 6889

106. Kumar A, Verma A, Gokhale A A, Bhambri R, Misra A, Sundriyal S, Dobhal D P and Kishore N (2018) Hydrometeorological assessments and suspended sediment delivery from a central Himalayan glacier in the upper Ganga basin International Journal of sediment Research 33 493-509

107. Kumar A, Gokhale A A, Shukla T and Dobhal D P (2016) Hydroclimatic influence on the particle size distribution of suspended sediments evacuated from debris-covered Chorabari Glacier, upper Mandakini catchment, central Himalaya Geomorphology 265 45-67

108. Kumar A, Mittal H, Kumar R and Ahluwalia R S (2016) Empirical Attenuation relationship for Peak Ground Horizontal Acceleration for North-East Himalaya, Vietnam Academy of Science and Technology Vietnam Journal of Earth Sciences 39 47-57

109. Kumar N and Khandelwal D D (2015) Strong motion data analysis of the 4 April 2011 Western Nepal earthquake (M 5.7) and its implications to the seismic hazard in the Central Himalaya Current Science 109 1822-1830

110. Kumar N and Kumar S (2018) Evidence of multifaceted 
SKS/SKKS splitting directions in the Sikkim Himalaya, India Journal of Geodynamics 117 12-20

111. Kumar N and Yadav D N (2019) Coda Q estimation for Kinnaur region and surrounding part of NW Himalaya Journal of Seismology 23 271-285

112. Kumar N, and Kumar S (2018) Evidence of multifaceted SKS/SKKS splitting directions in the Sikkim Himalaya, India Journal of Geodynamics 117 12-20

113. Kumar N, Chauhan V, Dhamodharan S, Rawat G, Hazarika D and Gautam P K R (2017) Prominent pre-cursory signatures observed in soil and water radon data at MPGO, Ghuttu for Mw 7.8 Nepal Earthquake Current Science 112 907-909

114. Kumar N, Kumar P, Chauhan V and Hazarika D (2017) Variable anelastic attenuation and site effect in estimating source parameters of various major earthquakes including Mw 7.8 Nepal and Mw 7.5 Hindukush earthquake by using far-field strong motion data International Journal of Earth Science 106 2371-2386

115. Kumar P, Joshi A, Kumar S, Sandeep and Lal S (2018) Determination of site effect and anelastic attenuation at Kathmandu, Nepal Himalaya region and its use in estimation of source parameters of 25 April 2015 Nepal earthquake $\mathrm{Mw}=7.8$ and its aftershocks including the 12 May $2015 \mathrm{Mw}=7.3$ event Natural hazards 91 10031023

116. Kumar S, Singh P, Singh P and Shekhar Chandra (2018) Estimation of scattering and intrinsic attenuation based on multiple lapse time window analysis in Sikkim Himalayan region, India Physics of the Earth and Planetary Interiors 284 1-9

117. Kumar Sushil and Sushil Rama (2015) Earthquake Data Sorting with Minimum Swap Operations, Advances in Intelligent Systems and Computing. In: Das, K.N. (ed.), Proceedings of Fourth International Conference on Soft Computing for Problem Solving. Springer 336 357-361Doi: 10.1007/978-81-322-2220-0_28

118. Kumar Sushil, Singh Priyamvada, Singh Pitam, Biswal S. and Parija M P (2016) Frequency-dependent attenuation characteristics of coda waves in the Northwestern Himalaya (India) region Journal of Asian Earth Sciences $117337-345$

119. Kumar V, Gupta V, Jamir I and Chattoraj S L (2019) Evaluation of Potential Landslide Damming; Case study of Urni landslide, Kinnaur, Satluj valley, India Geoscience Frontiers 10 753-767

120. Kumar V, Mehta M, Mishra A and Trivedi A (2017) Temporal Fluctuations and frontal area change of Bangni and Dunagiri glaciers from 1962 to 2013, Dhauliganga Basin, Central Himalaya India Geomorphology 284 88-98

121. Lal S, Joshi A, Sandeep, Tomer M, Kumar P, ChunHsiang Kuo, Che-Min Lin, Kuo-Liang Wen and Sharma M L (2018) Modeling of the strong ground motion of 25th April 2015 Nepal earthquake using a modified semiempirical technique Acta Geophysica 66 461-477

122. Lokho K, Saxena R K, Raju D S N and Kumar A (2017) Middle Miocene calcareous nannofossils from the Upper Bhuban Formation of Mizoram, Indo-Burma Range Micropaleontology 62 341-352

123. Lokho K, Singh BP, KezhakielieWhiso O and Chonchibeni Ezung (2018) Ichnology of the Laisong Formation (late Eocene-early Oligocene) of the Naga Hills, Indo-Burma range (IBR): Paleoenvironmental significance Journal of Asian Earth Sciences 162 13-24

124. Lokho K, Srivastava G and Mehrpotra R C (2017) A note on plant remains from the Paleogene sediments of the Naga Hills, Indo-Burma suture zone Himalayan Geology 38 86-90

125. Longkumer L, Luirei K, Moiya J N and Thong G T (2019) Neotectonic activity in parts of the Schuppen Belt of Mokokchung District, Nagaland: Evidence from morphotectonic features Journal of Asian Earth Sciences 170 138-154

126. Luirei K, Bhakuni S S and Kothyari G C (2015) Drainage response to active tectonics and evolution of tectonic geomorphology across the Himalayan Frontal Thrust, Kumaun Himalaya Geomorphology 239 58-72

127. Luirei K, Bhakuni S S and Kothyari G C (2018) Geomorphologic study of the valley floor in different tectonic segments along Kosi River valley between South Almora Thrust and Himalayan Frontal Thrust: Kumaun Himalaya, India Geological Journal 53 1500-1515

128. Luirei K, Bhakuni S S and Negi S S (2017) Landforms along transverse faults parallel to the axial zone of folded mountain front, northeastern Kumaun sub-Himalaya, India Journalof Earth System Science 126 1-19

129. Luirei K, Bhakuni S S, Kothyari G C, Tripathi K, and Pant P D (2016) Quaternary extensional and compressional tectonics revealed from Quaternary landforms along KosiRiver valley, outer Kumaun Lesser Himalaya, Uttarakhand International Journal of Earth Science (GeolRundsch) 105 965-981

130. Luirei K, Lokho K and Kothyari G Ch. (2018) Neotectonic activity along the Churachandpur-Mao Fault in and around Karong, Manipur, India: based on morphotectonics and morphometric analyses Arabian Journal of Geosciences 
$111-16$

131. Mahima, Karakoti I, Hemwati Nandan Hand Pathak P P (2017) A comparison between satellite-derived and ground measured solar radiation (global and diffuse) data for the metro cities of India Journal of Environment and Biosciences 31 473-477

132. Manish M, Bhambri R, Jayangondaperumal R, Srivastava P and Gupta A K (2017) Uttarakhand Calamity: A Climate Revelation in the Bhagirathi River Valley Uttarakhand India. Pal, I. \& Shaw, R. (eds.), Disaster Risk Governance in India, and Cross-Cutting Issues. Springer International Publishing Switzerland, 193-207

133. Maurya U K, Rai S K, Bartarya S K, Kumar A, Kumar A, Tiwari S, Thakur D, Maurya S and Sharma N K (2017) Hydrological behavior of natural springs/streams in midhills of Chakrata Himalaya, IndiaProceedings of the International Ground Water Conference in New Delhi (11113 Dec. 2017) Full paper IGCW-367

134. Meena N K, Prakasam M, Bhushan R, Sarkar S, Diwate P and Banerji U S (2017) Last five-decade heavy metal pollution records from the Rewalsar Lake, Himachal Pradesh, India Environmental Earth Sciences 7639 (DOI 10.1007/s12665-016-6303-0)

135. Mehta M, Shukla T, Bhambri R, Gupta A K, and Dobhal D P (2017) Terrain changes, caused by the 15-17 June 2013 heavy rainfall in the Garhwal Himalaya, India: A case study of Alaknanda and Mandakini basins Geomorphology $28453-71$

136. Mehta M, Dobhal D P, Shukla T and Gupta A K (2016) Instability Processes Triggered by Heavy Rain in the Garhwal Region, Uttarakhand, India. In: Singh, R.B. et al. (eds.), Climate Change, Glacier Response, and Vegetation. Springer International Publishing Switzerland, 219-234

137. Mishra P K, Prasad S, Jehangir A Anoop A, Yousuf A R and Gaye B (2018) Investigating the role of meltwater versus precipitation seasonality in abrupt lake-level rise in the high-altitude Tso Moriri Lake (India) Palaeogeography, Palaeoclimatology, Palaeoecology 493 20-29

138. Mishra P K, Prasad S, Marwan N, Ambili, A, Krishnan R, Gaye B, Basavaiah N, Stebich M, Menzel P and Riedel N (2018) Contrasting pattern of hydrological changes during the past two millennia from central and northern India: regionality of climate change or anthropogenic signal global and Planetary Change 161 97-107

139. Mishra R L, Jayangondaperumal R and Sahoo H (2016) Active tectonics of Dikrong valley, Northeast Himalaya, India: Insight into the differential uplift and fold propagation from river profile analysis Himalayan Geology 37 85-94

140. Mishra R L, Singh I, Pandey A, Rao P S, Sahoo, H K and Jayangondaperumal R (2016) Paleoseismic evidence of a giant medieval earthquake in the eastern Himalaya Geophysical Research Letters $\mathbf{4 3}$ 5707-5715

141. Mugnier J L, Vignon V, Jayangondaperumal R, Vassallo R, Malik M A, Replumaz A, Srivastava P, Jouanne F, Buoncristiani J F, Jomard H and Carcaillet J (2017) A complex thrust sequence in western Himalaya: The active Medlicott Wadia Thrust Quaternary International 462 109123

142. Mukherjee P K,Singhal S, Vikas, Rai, S K, Som Dutt, Kharya A and Gupta A K (2017) In-situ U-Pb microgeochronology of zircon, using LA-MC- ICPMS technique in mixed collector configuration Current Science 112 408410

143. Mukherjee P K, Souders A K and Sylvester P J (2019) Accuracy and precision of $\mathrm{U}-\mathrm{Pb}$ zircon geochronology at high spatial resolution (7-20 ìm spots) by laser ablationICP-single-collector-sector-field-mass spectrometry $J$ Analytical Atomic Spectrometry 34 180-194

144. Mundepi A K, Galiana-Merino J J, Asthana A K L and Rosa-Cintas S (2015) Soil Characteristics in Doon Valley (northwest Himalaya, India) by inversion of $\mathrm{H} / \mathrm{V}$ spectral ratios from ambient noise measurements Soil Dynamics and Earthquake Engineering 77 309-320

145. Nanda A-C and Sehgal R K (2015) Uplift-denudation of Himalaya: evidence from Cenozoic mammalian faunas. In: Siwalik mammalian faunas of the Himalayan foothills: with reference to bio-chronology, linkages and migration (chapter 9), WIHG Monograph Series, No. 2, 143-153

146. Nanda A-C, Scheich H H and Kotlia B S (2016) New Fossil Reptiles records from the Siwalik of North India Open Journal of Geology 6 673-691

147. Nanda A-C, Sehgal R K and Chauhan PR (2018) Siwalikage faunas from the Himalayan Foreland Basin of South Asia Journal Asian Earth Sciences 162 54-68

148. Negi P S (2018) Real-time monitoring of black carbon aerosols in the glaciated valley of northwestern Indian Himalaya Current Science 114 1161-1163

149. Negi S S and PaulA(2015) Space-time clustering properties of seismicity in the Garhwal-Kumaun, Himalaya Himalayan Geology 36 91-101

150. Negi S S, Paul A, Joshi A, and Kamal (2015) Body Wave Crustal Attenuation Characteristics in the Garhwal Himalaya, India Pure and Applied Geophysics 172 14511469 
151. Negi S S, Paul A, Simone C, Kamal Marius, Kriegerowski P, Mahesh and Gupta S (2017) Crustal velocity structure and earthquake processes of Garhwal-Kumaun, Himalaya: Constraints from regional waveform inversion and array beam modelling, Tectonophysics 712-713 45-63

152. Olsson R, Bhasin R K, Ragnarsson A, Richter B, Singh B, Bartarya S K, Rai S K and Rawat G (2015) Pilot Project study for Utilization of Geothermal Energy in NorthWestern Himalaya. In: Proceedings World Geothermal Congress, 2015 Melbourne, Australia, 19-25 April 2015, 8

153. Pandey A, Singh I, Mishra R L, Rao P S, Srivastava H B and Jayangondaperumal R (2018) Active tectonics in the Assam Seismic Gap between the meizoseismal zone of A.D. 1934 and 1950 earthquakes along the eastern Himalayan front, India J. Earth System Science 12766 117

154. Pandey C P (2017) Study of spectro-temporal variation in paleo-climatic marine proxy records using wavelet transformations AIP Conference Proceedings 1897 (1), 020019 (2017); doi: 10.1063/1.5008698

155. Pandey S and Parcha S K (2017) Provenance, tectonic setting and source-area weathering of the lower Cambrian sediments of the Parahio Valley in the Spiti basin, India Journalof Earth System Science 126 (DOI 10.1007/s12040017-0803-5)

156. Parcha S K and Pandey S (2016) Trace fossils and Microbially induced Sedimentary structure from the early Cambrian succession of ChandratalSpiti Basin, Tethys Himalaya. Journal of Palaeontological Society of India 60 21-26

157. Parida B R, Behera S N, Bakimchandra O, Pandey A-C and Singh N (2017) Evaluation of Satellite-derived Rainfall Estimates for an Extreme Rainfall event over Western Himalayas Hydrology 422 (DOI 10.3390/ hydrology4020022)

158. Parija M, Kumar S, Tiwari V M, Rao P C, Kumar N and Biswal S (2018) Microseismicity, Tectonics, and seismic potential in the Western Himalayan segment, NW Himalaya, India Journal of Asian Earth science 159 1-16

159. Parija M, Kumar S, Biswal S, Kumar N and Mishra S (2016) A preliminary one-dimensional crustal velocity model for Himachal Pradesh, India Journal of Seismology 20 305-318

160. Parijaa M P, Kumar S, Tiwari V M, Rao, N Purnachandra, Kumar N, Biswal S and Singh I (2018) Microseismicity, tectonics and seismic potential in the Western Himalayan segment, NW Himalaya, India Journal of Asian Earth
Sciences 159 1-16

161. Paul A and Kumar R (2017) Relevance of seismicity in Kumaun-Garhwal Himalaya in context of recent 25th April 2015 Mw7.8 Nepal earthquake Journal of Asian Earth Sciences 144 253-258

162. Paul A and Joshi V (2019) Assessment of seismic hazard in Kumaun-Garhwal region Himalayan Geology 40 78-82

163. Paul A, Hazarika and Wadhawan M (2017) Shear wave splitting and crustal anisotropy in the Eastern LadakhKarakoram zone, northwest Himalaya Journal of Asian Earth Sciences 140 122-134

164. Paul A, Prasath A and Singh R (2015) Slip heterogeneities evaluated for earthquakes $\mathrm{M}>4.0$ using waveform modeling in the Garhwal region of Central Seismic Gap in Northwest Himalaya, India Himalayan Geology 36 153-160

165. Paul A(2016) Strain energy budget analysis in the GarhwalKumaon region of Central Seismic Gap in Himalaya Himalayan Geology 37 113-120

166. Philip G, Suresh N and Jayangondaperumal R (2017) Late Pleistocene-Holocene strain release by normal faulting along the Main Boundary Thrust at Logar in the northwesternKumaon Sub Himalaya, India Quaternary International 462 50-64

167. Phukon P, Sen K, Srivastava H B, Singhal S and Sen A (2018) U-Pb geochronology and geochemistry from the Kumaun Himalaya, NW India, reveal Paleoproterozoic arc magmatism related to the formation of the Columbia supercontinent Geological Society of America Bulletin 130 1164-1176

168. Prakash D, Yadav R, Tewari S, Frimmel H E, Koglin N, Sachan H K and Yadav M K (2017) Geochronology and phase equilibria modelling of ultra-high temperature sapphirine+quartz-bearing granulite at Usilampatti, Madurai Block, Southern India Geology Journal 53 139158

169. Pratap B, Dobhal D P, Bhambri R, Mehta M and Tewari V C(2016) Four Decades of Glacier Mass balance Observations in the Indian Himalaya: A review Journal of Regional Environmental Change 16 643-658

170. Pratap B, Dobhal D P, Mehta M and Bhambri R (2015) Influence of debris cover and altitude on glacier surface melting: A case study on Dokriani Glacier, Central Himalaya, India Annals of Glaciology 56 9-16

171. Qasim M A, Ahmad A H M, Sachan H K and Ghosh S K (2019) Recrystallization and Provenance History of the Upper Kaimur Group Siliciclastics, Son Valley, India: Coupled Petrographic and Fluid inclusion Proxy Journal of the Geological Society of India 93 177-184 
172. Rai S K, Tiwari S K, Bartarya S K and Gupta A K (2015) Geothermal systems in the Northwest Himalaya Current Science 108 1597-1599

173. Rai S K, Tiwari S K, Kharya A, Negi M and Gupta A K (2015) A Laser-Based Fluorination (BrF5) System for the Extraction of Oxygen $(\mathrm{O} 2)$ from Silicate Rocks of Himalaya and ä180 Measurements: Method Establishment and Implications MAPAN 30 221-230

174. Raja P, Singh N, Srinivas C V, Singhal M, Chauhan P, Singh $\mathrm{M}$ and Sinha N K (2018)Analyzing energy-water exchange dynamics in the Thar desert Climate Dynamics 503281 3300

175. Raja P, Srinivas C V, Hari P, K B R R and Singh N (2016) Land Surface Processes Simulation Over Thar Desert in Northwest India Pure and Applied Geophysics 1732195 2214

176. Rajesh S and Majumdar T J (2015) Satellite-derived geoid for the estimation of Lithospheric cooling and basal heat flux anomalies over the Northern Indian Ocean Lithosphere Journal of Earth System Science (Springer) 124 16771691

177. Rajesh S, Majumdar T J and Krishna K S (2015) Lithospheric stretching and the long-wavelength free-air gravity anomaly of the Eastern Continental Margin of India and the $85 \mathrm{oE}$ Ridge, Bay of Bengal. Indian Journal of Geo-Marine Sciences 44 1-12

178. Rajesh S, Mundepi A K and Kumar N (2017) Quantifying seismic vulnerability, dynamical shear strain and liquefaction of the Quaternary deposits in the Doon valley near the Main Boundary Thrust in the Northwest Himalaya Quaternary International 462 162-175

179. Rajesh S, Pappachen John P and Mundepi A K (2018) Micro-Tremor Induced Gravity and Seismic Noise Spectra in the Garhwal Himalaya and the Adjoining Regions Journalof the Geological Society of India (JGSI) 91273 280

180. Rao D R and Daga Megha M (2015) Felsic granites vis-àvis leucosomes from the Shyok-Darbuk section of the Shyok Suture Zone, eastern Ladakh, India: A geochemical study Current Science 108 198-204

181. Rana R S, Kumar K, Zack S, Sole F, Rose K D, Missiaen P, Singh L, Sahni A and Smith T (2015) Craniodental and postcranial morphology of Indohyaenodonraoi from the early Eocene of India, and its implications for ecology, phylogeny, and biogeography of hyaenodontid mammals Journal of Vertebrate Paleontology 35 e965308, 22

182. Rao D R and Thakur S S (2017) Geochemistry of the mafic xenoliths from the Kinnaur Kailash Granite,
Baspavalley, Himachal Pradesh, India Journal of Geological Society of India 89 711-718

183. Rao P S, Jayangondaperumal R, Pandey A, Mishra R L, Singh I, Bhushan R, Srivastava P, Ramachandran S, Shah C, Kedia S, Sharma A K and Bhat G R (2017) Primary surface rupture of the 1950 Tibet-Assam great earthquake along the eastern Himalayan front, India Scientific Reports 75433

184. Rawat R S, Jowhar T N and Bhandari K (2015) Homogenisation experimental studies of alkali feldspars from the northwestern Himalayan granites, India. In: Shrivastava, K.L. \& Srivastava, P.K. (eds), Frontiers of Earth Science. Scientific Publishers (India), 437-449

185. Rawat S, Gupta A K, Sangode S J, Srivastava P and Nainwal H C (2015) Late Pleistocene-Holocene vegetation and Indian summer monsoon record from the Lahaul, Northwest Himalaya, India Quaternary Science Reviews 114167-181

186. Rawat S, Gupta AK, Srivastava P, Sangode S J and Nainwal HC (2015)A 13,000-year record of environmental magnetic variations in the lake and peat deposits from Chandra valley, Lahaul: Implications to Holocene monsoonal variability in the NW Himalaya PalaeogeographyPalaeclimatology Palaeoecology 440 116-127

187. Rose K D, Dunn R, Kumar K, Perry Prufrock, Rana R S and Smith T (2018) New Fossils from Tadkeshwar Mine (Gujarat, India) increase Primate Diversity from the early Eocene Cambay Shale Journal of Human Evolution 122 93-107

188. Sachan H K, Kharya A, Singh P C, Rolfo F, Groppo C and Tiwari S K (2017) A fluid inclusion study of blueschistfacies lithologies from the Indus suture zone, Ladakh (India): Implications for the exhumation of the subductionrelated Sapi-Shergolophiolitic mélange Journal of Asian Earth Sciences 146 185-195

189. Sachan H K, Santosh M, Prakash Divya, Kharya A, Singh P Chandra and Rai S K (2016) Metamorphic P-T conditions and $\mathrm{CO} 2$ influx history of medium-grade metapelites from the Karakorum, Trans-Himalaya, India Journal of Asian Earth Sciences 124 126-138

190. Samanta S, Dalai T K, Pattanaik J K, Rai S K and Mazumdar A (2015) Dissolved inorganic carbon (DIC) and its ä13C in the Ganga (Hooghly) River estuary, India: Evidence of DIC generation via organic carbon degradation and carbonate dissolution Geochimica et CosmochimicaActa $1652340-2355$

191. Samanta S, Dalai T K, Tiwari S K and Rai S K (2018) Quantification of source contributions to the water budgets 
of the Ganga (Hooghly) River estuary India Marine Chemistry 207 42-54

192. Sandeep, Joshi A, Lal Sohan, Kumar P, Sah S K, Kamal and Vandana (2017) Simulation of Strong Ground Motion of the 2009 Bhutan Earthquake Using Modified SemiEmpirical Technique Pure and Applied Geophysics 174 4343-4356

193. Sandeep, Joshi A, Sah S K, Kumar P, LalSohan, Vandana, Kamal and Singh R S (2017) Source model estimation of the 2005 Kyushu Earthquake, Japan using Modified SemiEmpirical Technique Journal of Asian Earth Sciences 147 240-253

194. Sangode S J, Meshram D C, Rawat S, Kulkarni Y, Chate D M and Gudahe S S (2017) Sedimentary and Geomorphic Signatures of a Cloud burst and triggered flash floods in the Indus valley of Ladakh Himalaya Himalayan Geology 38 12-29

195. Sangode, S J, Meshram D C, Rawat S, Suresh N and Srivastava P (2017) Sedimentary and geomorphic observations along Pangong strand of the Karakoram fault (NW Himalaya) depicting Holocene uplift Himalayan Geology 38 111-128

196. Sanguri M, Sharma R, Rao D R, Pandey M, and Sharma A K (2017) Syn- to Post-Metamorphic Fluids in the Central Crystallines of Kumaun Himalaya: Evidence from Fluid Inclusion study of the metapelites Himalayan Geology 38 56-67

197. Sarkar S, Agrawal S and Meena N K (2016) Late Quaternary paleoclimatic oscillation in the Ganga Plain, India during $\sim 59-26 \mathrm{ka}$ decoded from river cliff sediment archive Himalayan Geology 37 105-112

198. Sarkar S, Prakasam M, Banerji U S, Bhushan R, Meena N K and Gaury P K (2016) Rapid sedimentation history of Rewalsar Lake, Lesser Himalaya, India during the last fifty years - Estimated using $137 \mathrm{Cs}$ and $210 \mathrm{~Pb}$ dating techniques: A comparative study with other North-Western Himalayan Lakes Himalayan Geology 37 1-7

199. Sehgal R K (2015) Mammalian faunas from the Siwalik sediments exposed around Nurpur, District Kangra (H.P.): age and palaeobiogeographic implications Himalayan Geology 36 9-22

200. Sen A, Sen K, Srivastava H B, Singhal S and Phukon P (2018) Age and geochemistry of the Paleoproterozoic Bhatwari Gneiss of Garhwal Lesser Himalaya, NW India: implications for the pre-Himalayan magmatic history of the Lesser Himalayan basement rocks. Geological Society, London, Special Publications 481 SP481-6

201. Sen K, Adlakha V, Singhal S and Chaudhury R (2018)
Migmatization and intrusion of "S type" granites in the trans Himalayan Ladakh Magmatic Arc of north India and their bearing on Indo Eurasian collisional tectonics Geological Journal 53 1543-1556

202. Sen K, Chaudhury R and Pfänder J (2015) 40Ar-39Ar age constraint on deformation and brittle-ductile transition of the Main Central Thrust and the South Tibetan Detachment zone from Dhauligangavalley, Garhwal Himalaya, India Journal of Geodynamics 88 1-13

203. Sharma M, TiwariMeera, Ahmad S, Shukla R, Shukla B, Singh V K, Pandey SK, Ansari A H, Shukla Y and Kumar S (2016) Palaeobiology of Indian Proterozoic and Early Cambrian successions -Recent developments Proc Indian Nation Science Academy 82 559-579

204. Sharma S, Bartarya S K and Marh B S (2016) Post-glacial landform evolution in the middle Satluj river valley, India: Implications towards understanding the climate tectonic coupling Journal of Earth System Science 125 539-558

205. Sharma S, Chand P, Bisht P, Shukla A D, Bartarya S K, Sundriyal Y P and Juyal N (2016) Ascertaining the Role of Indian Summer Monsoons and Mid-latitude Westerlies in Driving the Glaciation in Sarchu Plain, Zanskar Himalaya during the late Quaternary Journal of Quaternary Science 31 495-511

206. Sharma S, Marh B S and Bartarya S K (2016) Role of preexisting valley topography in the post-glacial fluvial landform evolution in the middle Satluj valley, Western Himalaya, India Quaternary International 425 399-415

207. Sharma S, Shukla, A D, Bartarya S K, Marh B S and Juyal N (2017) The Holocene floods and their affinity to climatic variability in western Himalaya, India Geomorphology $290317-334$

208. Shukla A and Ali I (2016) A hierarchical knowledge-based classification for glacier terrain mapping - A case study from Kolahoi glacier Annals of Glaciology 57 1-10

209. Shukla A and Ali I (2017) Major river systems of Jammu \& Kashmir. In: Singh, D.S. (ed.), The Indian Rivers: Scientific and Socio-Economic Aspects. Springer publication 280-305

210. Shukla A and Qadir J (2016) Differential response of glaciers with varying debris cover extents: Evidence from changing glacier parameters International Journal of Remote Sensing 37 2453-2479

211. Shukla A and Yousuf B (2017) Evaluation of Multisource Data for Glacier Terrain Mapping: A Neural Net Approach Geocarto International 32 569-587

212. Shukla A, Ali I, Hasan N and Romshoo S A (2016) Dimensional changes in the Kolahoi Glacier from 1857 to 
2014 Environmental Assessment and Monitoring 189 118

213. Shukla T, Kumar V and Mehta M (2019) Response of the Himalayan glacial cycles to multiple equilibria of the climate system: A review Quaternary International 507 4-14

214. Shukla T, Mehta M, Kumar V, Nainwal H C, Dobhal D P (2017) Application of the Schmidt-hammer with relative age dating of moraine boulders- a case study from Mandakini River valley, Central Himalaya India Himalayan Geology 38 184-192

215. Shukla T, Mehta M, Jaiswal M K, Srivastava P, Dobhal D P, Nainwal H C and Singh A K (2018) Late Quaternary glaciations history of Monsoon dominated Dingad basin, central Himalaya, India Quaternary Science Reviews 181 43-64

216. Singh A K, Chung S L, Bikramaditya R K and Lee H Y (2017) New U-Pb zircon ages of plagiogranites from the Nagaland-Manipur Ophiolites, Indo-Myanmar Orogenic Belt,NE India Journal of the Geological Society, London 174 170-179

217. Singh A K, Khogen S, Kumar S, Singh R B, Khuman R K, Ch. Mangi and Thakur S S (2016) Evidence of Mid-ocean ridge and shallow subduction forearc magmatism in the Nagaland-Manipur ophiolites, northeast India: Constraints from mineralogy and geochemistry of gabbros and associated mafic dykes Chemie der Erde 76 605-620

218. Singh A K, Khogenkumar S, Subramanyam K S V, Thakur S S, Singh R K B and M Satyanarayanan (2017) Genesis and tectonic implications of cumulate pyroxenites and tectonite peridotites from the Nagaland-Manipur ophiolites, Northeast India: constraints from mineralogical and geochemical characteristics Geological Journal 52 415436

219. Singh D S, Gupta AK, Sangode S J, Clemens S C, Prakasam M, Srivastava P and Prajapati S K (2015) Multiproxy record of monsoon variability from the Ganga Plain during 400-1200 A.D. Quaternary International 371 157-163

220. Singh H, Prasad M, Kumar K and Singh S K (2015) Early Eocene macroflora and associated palynofossils from the Cambay Shale Formation, Western India: phytogeographic and palaeoclimatic implications Palaeoworld 24 293-323

221. Singh I B, Sahni A, Jain A K, Upadhya R, Parcha S K, Parmar V, Agarwal K K, Shukla S, Kumar S, Singh M P, Ahmad S, Jigyasu D K, Arya R and Pandey S (2015) PostIndia-Asia collision sedimentation (Indus Basin) in Ladakh, India: Implications for the evolution of the northern margin of Indian Plate Journal of Palaeontological Society of India 60 97-142
222. Singh KA, Singh Y R, Devi S R, Singh B P and Srivastava V K (2019) Depositional environments of the Surma Group of Tamenglong area, North-western Manipur, IndoMyanmar Ranges: Mineralogical and palynological constraints Himalayan Geology 40 83-91

223. Singh N, Patel N R, Singh J, Raja P, Soni P and Parihar J S (2016) Carbon exchange in some invasive species in the Himalayan foothills Tropical Ecology 57 263-270

224. Singh N, Patel N R, Singh J, Raja P, Soni P and Parihar J S (2016) Carbon exchange in some invasive species in the Himalayan foothills Tropical Ecology 57 263-270

225. Singh P, Kumar S, and Singh P (2018) Attenuation of shortperiod body waves in Northwestern Himalayan Region, India Soil Dynamics and Eq Eng 114 555-562

226. Singh R, Paul A, Kumar A, Kumar P and Sundriyal Y P (2018) Estimation and applicability of attenuation characteristics for source parameters and scaling relations in the Garhwal Kumaun Himalaya region Journal of Asian Earth Sciences 159 42-59

227. Singh R, Prasath R A, Paul A and Kumar N (2018) Earthquake swarm of Himachal Pradesh in Northwest Himalaya and its Seismotectonic implications Phys Earth Planet Int 275 44-55

228. Singh R K B, Singh A K, Sen K and Sangode S J (2017) Detection of a weak late-stage deformation event in granitic gneiss through anisotropy of magnetic susceptibility: implications for the tectonic evolution of the Bomdila Gneiss in the Arunachal Lesser Himalaya, Northeast India Geological Magazine 154 476-490

229. Singh V, Yadav R R, Gupta A K, Kotlia B S, Singh J, Yadava A K, Singh A K and Misra K G (2017) Tree ring drought records from Kishtwar, Jammu and Kashmir, northwest Himalaya, India Quaternary International 444 53-64

230. Singh Y R, Singh B P, Singh, A K and Devi S R (2017) Palynology and Mineral Composition of the Upper Disangflyschoid sediments from the Southern Manipur, Northeast India: Age, Paleoenvironment and Provenance Reconstruction Himalayan Geology 38 1-11

231. Singhal S, Mukherjee P K, Saini N K, Dutt S and Kumar R (2019) Effect of carbon on major element analysis of carbonaceous silicate rocks by WD-XRF: An evaluation of error and its correction Geochemistry: Exploration, Environment, Analysis 19 31-38

232. Sinha S, Kumar R, Ghosh S K and Sangode S J (2015) Late Miocene expansion and contraction of piedmont plains in the Himalayan Foreland Basin: Implication to tectonic vs. climatic forcing Himalayan Geology 36 48-64 
233. Smith T, Kumar K, Rana R S, Folie A, Sole F, Noiret C, Steeman T, Sahni A and Rose K D (2016) New early Eocene vertebrate assemblage from Tadkeshwar Lignite Mine, India reveals a mixed fauna of Laurasian and Gondwanan origins Geoscience Frontiers 7 969-1001

234. Smith T, Sole F, Missiaen P, Rana RS, Kumar K, Sahni A and Rose K D (2015) First early Eocene tapiroid from India and its implication for the paleobiogeographic origin of perissodactyls Palaeovertebrata 39 e5

235. Soni A S, Soni V S Suresh N and Kumar R (2017) A unique stone-age collection from the late mid-Holocene terraces of River Satluj in the NW Sub-Himalayas of India Human Biology Review 6 301-324

236. Srivastava P, Agnihotri R, Sharma D, Meena N, Sundriyal Y P, Saxena A, Bhushan R, Sawlani R, Banerji U S, Sharma $\mathrm{C}$ and Bisht P (2017) 8000-year monsoonal record from Himalaya revealing reinforcement of tropical and global climate systems since mid-Holocene Scientific Reports 7 14515

237. Srivastava P, Kumar A, Chaudhary S, Meena N, Rawat S, Sundriyal Y P, Kumar N, Jayangondaperumal R, Bhist P, Sharma D, Juyal N, Wasson R J and Zieglar A (2017) Paleoflood records in Himalaya Geomorphology 284 1730

238. Srivastava P, Ray Y, Phartiyal B and Sundriyal Y P (2016) Rivers in the Himalaya: Responses to Neotectonics and Past Climate Proc Indian National Science Academy $\mathbf{8 2}$ $763-772$

239. Srivastava V, Srivastava P, Srivastava H B and Ray $Y$ (2015) Tectonic Consideration for Location of the Kishau Dam Site on Tons River in Lesser Himalaya, India Engineering Geology for Society and Territory (Sprinter) $1495-498$

240. Sundriyal S, Shukla T, Tripathi L, Dobhal D P, Tiwari S K and Bhan U (2018) Deposition of atmospheric pollutant and their chemical characterization in snowpit profile at Dokriani Glacier, Central Himalaya Journal of Mountain Science 15 2236-2246

241. Sundriyal Y P, Shukla A D, Rana N, Jayangondaperumal R, Srivastava P, Chamyal L S, Sati S P and Juyal N (2015) Terrain response to the extreme rainfall event of June 2013: Evidence from the Alaknanda and Mandakini River Valleys, Garhwal Himalaya, India Episodes 38 179-188

242. Tandon, R S and Gupta V (2015) Estimation of strength characteristics of different Himalayan rocks from Schmidt hammer rebound, point load index and compressional wave velocity Bulletin of Engineering Geology and Environment 74 521-533
243. Tandon R S, Gupta V and Sen K K (2015) Seismic properties of naturally deformed quartzites of the Alaknanda valley, Garhwal Himalaya, India Journal of Earth System Science 124 1159-1175

244. Thakur D, Bartarya S K and Nainwal H C (2018) Mapping groundwater prospect zones in an intermontane basin of the Outer of the Outer Himalaya in India using GIS and remote sensing techniques Environmental Earth Sciences 77368

245. Thakur D, Bartarya S K and Nainwal H C (2018) Tracing ionic sources and geochemical evolution of groundwater in the Intermountain Una basin in outer NW Himalaya, Himachal Pradesh, India Environmental Earth Sciences 77 720

246. Thakur S S, Madhavan K, Patel S C, Rao D R Singh A K, Pandey S and Nandini P (2018) Yttrium-zoning in garnet and stability of allanite in metapelites from the Main Central Thrust Zone and adjacent higher Himalayan crystallines along the Alaknanda Valley, NW Himalaya Lithos 320-321 1-19

247. Thakur S S, Patel A K and Singh A K (2015) A P-T pseudosection modelling approach to understand metamorphic evolution of the Main Central Thrust Zone in the Alaknanda valley, NW Himalaya Contribution to Mineralogy and Petrology 1702 (DOI 10.1007/s00410015-1159-y)

248. Thakur S S, Singh A K, Rao, D R, Sharma R, Pandey S and Ao A (2018) Garnetiferous metamorphic rocks in Jaspa granite, Himachal Pradesh, India: implication of Tethys Himalayan metamorphism and tectonics Current Science 115 1576-1583

249. Thakur V C, Jayangondaperumal R and V Joevivek (2018) Seismotectonics of Central and NW Himalaya: plate boundary - wedge thrust earthquakes in thin - and thickskinned tectonic framework Geological Society of London, Special Publications $\mathbf{4 8 1} 23$

250. Thakur V C and Jayangondaperumal R (2015) Seismogenic active fault zone between $2005 \mathrm{Kashmir}$ and 1905 Kangra earthquake meizoseismal regions and earthquake hazard in eastern Kashmir seismic gap Current Science 109 610-617

251. Thakur D, Bhartarya S K and Nainwal H C (2018) Groundwater quality assessment of the Soan Basin in Outer Himalaya, Himachal Pradesh, India Himalayan Geology 39 197-211

252. Tiwari R K, Garg P K, Shukla A, Ahluwalia R S, Singh N and Chauhan P (2016) A geomorphic and morphometric analysis of surface ice velocity variation of different valley type glaciers. Proc. volume 9877, Land Surface and 
Cryosphere Remote Sensing III (DOI 10.1117/12.2227108)

253. Tiwari S K, Bartarya S K, Rai S K, Gupta A K and Asthana A K L (2016) Isotopic and Geochemical studies of groundwater from Ramganga and middle Ganga plains: Implication to pollution and metal contamination Environmental Earth Sciences 751170 (DOI 10.1007/ s12665-016-5971-0)

254. Tiwari S K, Kumar A, Gupta A K, Verma A, Bhambri R, Sundriyal S and Yadav J (2017) Hydrochemistry of Dokriani Glacier meltwater during early and late ablation season, West Central Himalaya Himalayan Geology 39 $121-132$

255. Tiwari S K, Rai S K, Bartarya S K, Gupta A K and Negi M (2016) Stable isotopes (ä13CDIC, äD, ä18O) and geochemical characteristics of geothermal springs of Ladakh and Himachal (India): Evidence for $\mathrm{CO} 2$ discharge in northwest Himalaya Geothermics 64 314-330

256. Tiwari S K, Singh R K, Singh J, Gupta A K, Bartarya S K and Rai S K (2015) Impact of limestone mining activities on major ion geochemistry of KremMarkhyrdop water, Meghalaya, India Himalayan Geology 36 74-80

257. Tiwari S K, Singh R K, Singh J, Gupta A K, Bartarya S K and Rai S K (2015) Impact of limestone mining activities on major ion geochemistry of KremMarkhyrdop water, Meghalaya, India Himalayan Geology 36 74-80

258. Tripathi S, Tiwari M, Lee Jongmin, Khim Boo-Keun, Pandey D, Clift,P D, Kulhanek D, Ando S, Bendle J A, Bratenkov P S, Griffith E M, Grumurthy G P, Hahn A, Iwai M, Kumar A, Kumar A G, Liddy H M, Lu H, M W Lyle, Mishra R T, Radhakrishna, Routledge C M, Saraswat R, Saxena R, Scardia G, Sharma G K, Singh AD, Steinke S, Suzuki K, Tauxe L, Xu Z and Yu Z (2017) First evidence of OMZ evolution versus monsoon in Eastern Arabian Sea since late Miocene Scientific Report 743056 doi:10.1038/ srep43056

259. Trivedi A, Kumar V, Mishra A and Awasthi R (2017) Modern palynological census of Dunagiri Valley: Distribution and its relationship with past vegetation and climate Journal of Palaeontological Society of India $\mathbf{6 2}$ 237-241

260. Vassallo R, Mugnier J-L, Vignon V, Malik M A, Jayangondaperumal R, Srivastava P, Jouanne F and Carcaillet J (2015) Distribution of the Late-Quaternary deformation in Northwestern Himalaya Earth and Planetary Science Letters 411 241-252

261. Verma A, Kumar A, Gupta A K, Tiwari S K, Bhambri R and Naithani S (2018) Hydroclimatic significance of stable isotopes in precipitation from glaciers of Garhwal
Himalaya, Upper Ganga Basin(UGB), India Hydrological Processes 32 1874-1893

262. Vignon V, Mugnier J L, Vassallo R, Srivastava P, Malik M A, Jayangondaperumal R, Jouanne F, Buoncristiani J F, Carcaillet J, Replumaz A and Jomard H (2017) Sedimentation close to the active Medlicott Wadia Thrust (Western Himalaya): How to estimate climatic base-level changes and tectonics Geomorphology 284 175-190

263. Vyshnavi S, Islam R and Sundriyal Y P (2015) Comparative study of soil profiles developed on metavolcanic (basaltic) rocks in two different watersheds of Garhwal Himalaya Current Science 108 699-707

264. Wadhawan M, Hazarika D, Paul A, Kumar N, Thakur S S, and Gupta V (2017) Crustal thickness and Poisson's ratio variation in the Satluj valley, Northwest Himalaya Himalayan Geology 38 38-48

265. Yadav D K, Hazarika D and Kumar N (2016) Seismicity and stress inversion study in the Kangra-Chamba region of Northwest Himalaya Natural Hazards 82 1393-1409

266. Yadav D K, Kumar N and Hazarika D (2015) Stress pattern of NW Himalaya: Stress coupling between higher Himalaya and south Tibetan Plateau. In: Ramola R C and Gusain G $\mathrm{S}$ (eds.) Proceedings of International Conference on GeoHazards: Recent Research 111-119

267. Yadav D K, Kumar N, Hazarika D, Yadav D N and Wadhawan M (2017) Seismicity and tectonics of Kinnaur Himalaya and adjoining region inferred from focal mechanism solutions and stress tensor inversion Himalayan Geology 38 49-55

268. Yadav R K, Gahalaut V K, Bansal A K, Sati S P, Joshi C, Gautam P K R, Kumar K and Rana N (2019) Strong seismic coupling underneath Garhwal-Kumaun region, NW Himalaya, India Earth and Planetary Science Letters 506 8-14

269. Yadava A K, Braeuning A, Singh J and Yadav R R (2016) Boreal spring precipitation variability in the cold arid western Himalaya during the last millennium, regional linkages, and socio-economic implications Quaternary Science Reviews 144 28-43

270. Yadava A K, Sharma Y K, Dubey B, Singh J, Singh V, Bhutiyani M R, Yadav R R and Misra K G (2017) Altitudinal treeline dynamics of Himalayan pine in western Himalaya, India Quaternary International 444 44-52

271. Yadava A K, Yadav R R, Misra K G, Singh J and Singh D (2015) Tree ring evidence of late summer warming in Sikkim, northeast India Quaternary International 371 175180 
272. Yu Z, Colin C, Shiming Wan, Saraswat R, Lina Song Zhaokai, Xu Peter, Clift, Huayu, Lu Mitchell, Lyle Denise, Kulhanek Annette Hahn, Tiwari M, Mishra R, Serge Miska and Kumar A (2019) Sea level-controlled sediment transport to the eastern Arabian Sea over the past $600 \mathrm{kyr}$ : Clay minerals and $\mathrm{Sr}-\mathrm{Nd}$ isotopic evidence from IODP site U1457 Quaternary Science Reviews 205 22-34

273. Zaccarini F, Singh A K, Garuti G and Satyarayanan M (2017) Platinum-group minerals (PGM) in the chromitite from the Nuasahi massif, eastern India: further findings and implications for their origin European Journal of Mineralogy 29 571-584 DOI: 10.1127/ejm/2017/00292637

274. Ziegler A D, Cantarero S I, Wasson R J, Srivastava P, Spalzin S, Chow W and Gillen J (2016) A Clear and Present Danger: Ladakh's increasing vulnerability to flash floods and debris flows Hydrological Processes 30 4214-4223. 